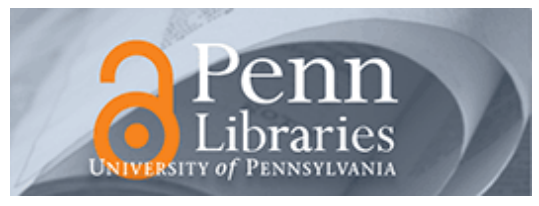

University of Pennsylvania ScholarlyCommons

\title{
To Share or Not to Share? Professional Norms, Reference Groups, and Information Withholding Among Life Scientists
}

Martine Haas

University of Pennsylvania

Sangchan Park

Follow this and additional works at: https://repository.upenn.edu/mgmt_papers

Part of the Business Administration, Management, and Operations Commons

\section{Recommended Citation}

Haas, M., \& Park, S. (2010). To Share or Not to Share? Professional Norms, Reference Groups, and Information Withholding Among Life Scientists. Organization Science, 21 (4), 873-891. http://dx.doi.org/ 10.1287/orsc. 1090.0500

This paper is posted at ScholarlyCommons. https://repository.upenn.edu/mgmt_papers/21

For more information, please contact repository@pobox.upenn.edu. 


\title{
To Share or Not to Share? Professional Norms, Reference Groups, and Information Withholding Among Life Scientists
}

\begin{abstract}
Why do scientists withhold information from colleagues, violating the professional norm of sharing? Norm violations are usually attributed to individual interests that lead scientists to reject professional norms. In contrast, we take the view that norm violations can occur when professional norms are valued but it is difficult to ascertain the appropriate course of professional conduct. This view suggests that scientists may look to cues from their professional reference groups to resolve sociological ambivalence arising from conflicting role expectations. We analyze a data set of 1,251 geneticists and other life scientists from 100 U.S. universities and find that beyond individual-level explanations, information withholding is influenced by the behaviors of peers as well as the attitudes of superiors in the profession. We discuss the implications for the professions literature, theories of organizational learning, and knowledge management initiatives in firms.
\end{abstract}

\section{Keywords}

information sharing/withholding, knowledge transfer, reference groups, professions, science

\section{Disciplines}

Business Administration, Management, and Operations 
TO SHARE OR NOT TO SHARE?

PROFESSIONAL NORMS, REFERENCE GROUPS, AND

INFORMATION WITHHOLDING AMONG LIFE SCIENTISTS

\author{
Martine R. Haas \\ The Wharton School \\ University of Pennsylvania \\ 2000 Steinberg-Dietrich Hall \\ Philadelphia, PA 19104, U.S.A. \\ e-mail: mrhaas@wharton.upenn.edu
}

Sangchan Park

NUS Business School

National University of Singapore

\#03-28 BIZ 2

Singapore 117592

e-mail: bizsp@nus.edu.sg

Acknowledgments: We thank Associate Editor Bill McEvily and the three reviewers on this paper for their helpful feedback throughout the review process. We also thank the scientists we interviewed for the study, seminar participants at MIT Sloan, and Eric Campbell, Jin Chung, Brandon Lee, Mike Lounsbury, Mitchell Orenstein, Jason Owen-Smith, Kelly Patterson, Pam Tolbert, and Freek Vermeulen for their valuable input. The data collection was supported by a grant from the National Human Genome Research Institute of the National Institutes of Health (grant 1R01HG01789-01). 


\title{
TO SHARE OR NOT TO SHARE? \\ PROFESSIONAL NORMS, REFERENCE GROUPS, AND \\ INFORMATION WITHHOLDING AMONG LIFE SCIENTISTS
}

\begin{abstract}
Why do scientists withhold information from colleagues, violating the professional norm of sharing? Norm violations are usually attributed to individual interests that lead scientists to reject professional norms. In contrast, we take the view that norm violations can occur when professional norms are valued but it is difficult to ascertain the appropriate course of professional conduct. This view suggests that scientists may look to cues from their professional reference groups to resolve sociological ambivalence arising from conflicting role expectations. We analyze a dataset of 1,251 geneticists and other life scientists from 100 U.S. universities and find that beyond individual-level explanations, information withholding is influenced by the behaviors of peers as well as the attitudes of superiors in the profession. We discuss the implications for the professions literature, theories of organizational learning, and knowledge management initiatives in firms.
\end{abstract}

Keywords: information sharing/withholding, knowledge transfer, reference groups, professions, science 
Organizational scholars have established that information withholding - the intentional failure to share potentially useful information with others - can impede intra-organizational learning processes that are critical for successful firm performance (see Argote and Ophir 2002 for a review). For example, information withholding within an organization can hinder that organization's ability to transfer best practices, learn from mistakes, stimulate innovation, or benefit from strategic alliances (e.g., Brown and Duguid 1991, Edmondson 1996, Szulanski 1996, Larsson et al. 1998, Reagans and McEvily 2003). Information withholding beyond the organization's borders can also reduce its potential for innovation, growth, and effectiveness, however, by impeding the advancement of knowledge about spheres of activity that are critical to its work. In particular, information withholding among academic scientists is widely believed to obstruct the advancement of scientific knowledge by preventing them from challenging, verifying, and building on each others' research (Polanyi 1962, Bok 1982, Nelkin 1984). Since scientific knowledge is vital to the success of firms in numerous industries, including high technology, biotechnology, pharmaceuticals, chemicals, and energy (e.g., Bierly and Chakrabarti 1996, Liebeskind et al. 1996, Almeida and Kogut 1999, Cohen et al. 2000, Murray 2004, Owen-Smith and Powell 2004), it is important to understand why information withholding occurs in science. ${ }^{1}$

Prior theory and research has offered two contrasting perspectives on this question. In Merton's seminal paper on the normative structure of science, he argued that the academic science profession is characterized by a fundamental macro-level norm of communalism, or "communism," that obliges scientists to place their research in the public domain through full and open sharing with the scientific community as early as possible in the discovery process (Merton 1973 [1942]). Yet this ideal of openness is often breached, as attested by gossip about withholding incidents that circulates among scientists, reports in the popular press, and growing concern about whether commercialization encourages secrecy (e.g., Argyres and Liebeskind 1998, Cook-Deegan and MacCormack 2001, Louis et al. 2001, Walsh and Hong 2003, Murray and Stern 2007). Emphasizing a fundamental norm of communalism without addressing the exercise of agency by individual scientists who choose to withhold thus presents an oversocialized account of professional conduct (cf. Granovetter 1985). In contrast, a series of papers published 
in the leading medical journals has responded to the concern about increasing incentives for secrecy among academic scientists by examining micro-level predictors of withholding behavior (e.g., Blumenthal et al. 1997, Campbell et al. 2002, Blumenthal et al. 2006). By focusing on individual activities and attributes, such as engagement in commercial activities (e.g., Campbell et al. 2002), these studies imply that scientists' decisions to withhold or share information are determined by their individual interests. This perspective provides useful insight into who withholds, but its account of withholding behavior is under-socialized in that it largely overlooks the influence of the social context in which scientists operate (cf. Granovetter 1985).

To steer a middle course between the over-socialized and under-socialized accounts of information withholding, we offer a meso perspective that proposes that academic scientists look to reference groups within the profession to guide their professional conduct, not simply either to a fundamental norm of communalism or to their own individual interests. Following the sociological literature on professions, we view norms as morally regulated role expectations for members of the profession (Goode 1957, Wilensky 1964, Merton 1973 [1942], Freidson 2001). However, we depart from the traditional characterization of professional norms by suggesting that their influence operates at the level of reference groups embedded within the profession rather than more broadly across the profession. We argue that scientists look to professional reference groups to guide their behavior because their professional role expectations are often conflicting rather than clear. These conflicting role expectations create "sociological ambivalence"- uncertainty about the appropriate course of professional conduct—that makes it difficult to weigh a fundamental norm of communalism against individual interests (Merton and Barber 1963, Merton 1976).

We define professional reference groups as subsets of individuals within the profession who serve as potential sources of social influence for their members as well as non-members (cf. Merton 1968, Hyman and Singer 1968). Consistent with prior research that uses externally observable criteria such as organizational roles or social categories to establish reference group membership (e.g., Goodman 1974, Singh 1994, Terry et al. 1999), we identify reference group members as those who share common 
professional characteristics that differentiate them from non-members, such as the same specialty or rank. In contrast to an emic (participant-defined) approach, which relies on scientists to identify the members of their reference groups by name, this etic (observer-defined) approach can capture broad social influences that are not necessarily based on established relationships (cf. Knorr-Cetina 1982, Lawrence 2006). We develop hypotheses concerning the influence of professional reference groups on information withholding by scientists and examine boundary conditions for this influence that arise from the characteristics of the group members, their behaviors and attitudes, and the focal scientists themselves. Building on the prior research on withholding among scientists, we focus on the life sciences community, particularly geneticists. We use interview data to briefly illustrate the conflicting role expectations that these scientists face and how reference groups influence them, and then test our hypotheses using quantitative survey data from a national study of 1,251 life scientists at 100 leading U.S. research universities.

\section{INFORMATION WITHHOLDING AMONG LIFE SCIENTISTS}

\section{Macro and Micro Perspectives}

Academic scientists regularly receive requests for information related to their research, where information refers to research-related findings, methods, data, or materials (McCain 1991, Hilgartner and Brandt-Rauf 1994). For example, scientists are often asked to share their research protocols, data sets, and biomaterials such as cell lines or antibodies. Even when the research results are already published in journals or technical reports, these formats frequently omit critical information that cannot be published, such as clones, algorithms, software, or detailed descriptions of techniques. Some journals state formal policies about an author's responsibilities related to sharing publication-related data and materials, but their scope is typically limited to making this information available to editors and reviewers if they ask for it, and about half of the 56 most cited life science and medical journals have no such policy at all (National Research Council 2003). Thus, scientists who want to replicate or extend the results of published studies frequently approach the authors of these studies directly to request additional sharing. 
The importance of information sharing for the progress of science provides the functional imperative for the professional norm of communalism. In Merton's early formulation of this norm, he stated, "Secrecy is the antithesis of this norm; full and open communication its enactment" (Merton 1973 [1942]: 274). This suggests that information withholding is a violation of a uniformly revered norm of sharing, a socially unacceptable and morally unjustifiable act. Sociological theories of professions have argued that such strong norms are inculcated through rigorous professional socialization, using methods such as formal training and apprenticeships, and then reinforced by rewards of recognition and the threat of social sanctions (Merton et al. 1957, Hagstrom 1965, Freidson 2001). Despite this characterization of professions as governed by deeply entrenched macro-level norms, however, individual members of professions often engage in behavior that violates these norms (Pavalko 1988, Leicht and Fennell 2001).

Although a macro perspective does not directly explain why individuals sometimes withhold information, the implication is that such norm violations occur when poorly socialized scientists reject the fundamental norm of communalism in favor of their individual interests. Whereas a strong collective identity encourages group members to uphold a norm of generalized exchange (Flynn 2005), social loafing and free-riding behaviors are more common when group members feel lower levels of identification with the group (Kidwell and Bennett 1993). Similarly, when professional socialization is insufficient or ineffective, scientists whose individual interests favor withholding may reject the fundamental norm of communalism because they see the personal advantages of withholding as more important to them than the rewards and sanctions of the profession that mandate sharing.

This explanation for withholding behavior provides the rationale for research that focuses on individual-level predictors of information withholding (e.g., Campbell et al. 2002, Blumenthal et al. 2006). Prior studies from this micro perspective have shown that scientists are more likely to withhold information not only if they are more involved in commercial activities or receive more industry support, but also if they receive more requests, conduct research on human subjects, or are male (Campbell et al. 2002). Similarly, the tension between a norm of communalism and individual interests suggests that scientists will withhold more if others have denied their requests in the past, if their academic mentors 
were less willing to share their own information with other scientists, or if they perceive competition for recognition or scientific priority in their area to be more intense (cf. Walsh et al. 2007).

\section{A Meso Perspective}

Both the macro and micro perspectives on information withholding assume that professional norms provide clear role expectations that individuals choose to follow or reject by weighing the costs and benefits of violating them. However, professionals often face conflicting rather than clear role expectations, as Merton himself recognized in his later writings (Merton and Barber 1963, Merton 1976). Merton's original conceptualization of the normative structure of science has long dominated characterizations of the scientific profession, as well as critiques that argue that this conceptualization views actors as unduly constrained (e.g., Mulkay 1969, Knorr-Cetina 1999, Sismondo 2004). But Merton later departed from his initial view to propose that science is "patterned in terms of potentially conflicting pairs of norms," rather than governed by fundamental norms that serve as clear guides to professional conduct (Merton 1976: 33). For example, scientists' roles demand originality, encouraging them to strive to be first to announce a significant discovery, but also humility, discouraging them from fighting for priority if multiple investigators announce a discovery simultaneously (Merton 1963).

Merton argued that such juxtapositions of dominant norms and counter-norms create "sociological ambivalence" in the form of "inner conflict among scientists who have internalized both of them" (Merton 1976: 36). ${ }^{2}$ Despite Merton's modifications of his early views on scientific norms, the ideas of conflicting norms and sociological ambivalence have been largely neglected (for exceptions, see Mitroff 1974, Mills 1983, Etzkowitz 1989). In particular, neither Merton nor the few scholars who have built on these ideas have addressed the implications for communalism specifically or explained how scientists resolve sociological ambivalence. We address these gaps by arguing that scientists are aware of counter-normative expectations of information withholding that conflict with the dominant normative expectations of information sharing, and that this creates sociological ambivalence for them. It is possible that scientists who face such contradictory role expectations may simply decide to act according to their individual interests, as prior research suggests. But we propose that rather than rejecting professional 
norms entirely, scientists often attempt to resolve the resulting ambivalence in a professionally acceptable way by looking to their reference groups within the profession for cues to guide their behavior. Below, we develop hypotheses about how the withholding behaviors and attitudes of reference group members influence a scientist's propensity to withhold information, and we also address the influence of other reference group characteristics on information withholding.

\section{Influence of Reference Group Withholding Cues}

Professional reference groups can exert influence over individuals who do not belong to the group themselves or even interact with the group members (Merton 1968, Singer 1981). This distinguishes them conceptually from other potential sources of influence such as social networks, institutional affiliations, or work groups. As well as exerting direct influence through interpersonal exchanges with the members, professional reference groups can also exert indirect forms of influence on scientists, including cognitive influence through shared experiences (Strang and Meyer 1993), relational influence through others' awareness of them (Lawrence 2006), and motivational influence through non-members' aspirations to join the group in the future (Merton 1968).

Members of the scientific profession can have multiple reference groups. The life sciences community, for example, encompasses a number of professional fields, including genetics, biochemistry, microbiology, and pathology, among others. Other life scientists in the same field constitute a potential reference group for a life scientist. Within the field of genetics, which is the main focus of our study, scientists have a professional specialty based on the model organism on which they work, such as bacteria, yeast, or humans. For a geneticist specializing in bacteria, other geneticists specializing in bacteria constitute a potential reference group of more similar colleagues. Within each specialty, further subgroups of still more similar colleagues can be identified on the basis of professional status, which refers here to a position in the hierarchy of the profession that carries social significance (Abbott 1981). Professional status characteristics are achieved rather than ascribed (i.e., earned through abilities and effort) and often serve as a social cue that individuals use to evaluate others' competence or expertise (Berger et al. 1980). For example, an important professional status characteristic in the academic life 
sciences community is a scientist's academic rank (cf. Campbell et al. 2002, Blumenthal et al. 2006, Owen-Smith 2001). We view scientists of the same professional status as the focal scientist (e.g., the same rank) as potential reference groups of status-equals, and those of higher professional status than the focal scientist (e.g., higher rank) as potential reference groups of status-superiors.

The conduct of reference group members serves as a cue for scientists faced with conflicting role expectations by influencing the visibility and acceptability of withholding behavior. If withholding behavior by reference group members is not visible, scientists are likely to conclude that it is not a viable option for them; in contrast, visible withholding behavior by others can encourage emulation (cf. Bamberger and Biron 2007, Marsden and Friedkin 1993). If withholding behavior appears socially unacceptable, it would seem to threaten the rewards that the reference group can provide and increase the risk of sanctions. For example, colleagues might reject a funding application, recommend against a promotion, or spread gossip that is reputationally damaging for a scientist who engages in unacceptable behavior (cf. Burt and Knez 1996).

Higher levels of information withholding among the members of a scientist's reference groups increase the likelihood that a focal scientist will also engage in withholding behavior. When levels of withholding in reference groups are higher, the visibility of such behavior increases because the scientist is more likely to personally experience, observe, or hear about a withholding incident (cf. Merton 1968). The scientist also runs a lower risk of having his or her own withholding behavior noticed when others engage in similar behavior, since any particular withholding incident is less worthy of attention. Higher levels of withholding in reference groups also increase the acceptability of withholding behavior because the scientist's own withholding behavior becomes more legitimate to the extent that more group members engage in it (cf. DiMaggio and Powell 1983). Further, if other scientists have withheld information themselves, they are likely to be less critical of a scientist who withholds. Hence:

HYPOTHESIS 1 (H1). Information withholding by reference group members will have a positive influence on withholding by a scientist. 
Information withholding in reference groups composed of scientists who are more professionally similar to a focal scientist in their field, specialty, and status can be expected to be more influential for that scientist because homophily_-preference for similar others-is a strong basis for influence in social contexts (e.g., Festinger 1954, Lazarsfeld and Merton 1954, Ibarra 1992). Since social cues are more salient when they come from more similar others, withholding behavior by more similar others attracts more attention from the focal scientist, heightening its visibility. Similarly, withholding among more similar others is more important for legitimizing the scientist's own withholding behavior. Even for scientists who do not care whether their behavior is acceptable to their colleagues, the behaviors of others who are more professionally similar to them may still matter more than those of less similar others because they serve as signals about the competitive landscape: if professionally similar colleagues frequently withhold information, scientists might decide that sharing information would put them at a disadvantage.

\section{HYPOTHESIS 2 (H2). Information withholding by reference group members will have a more positive} influence on withholding by a scientist if the group members are more professionally similar to the scientist.

If withholding by reference group members serves as a cue that guides the behaviors of scientists, the influence of this cue can be expected to be greater when the cue is less ambiguous. The influence of withholding behavior by reference group members thus will be stronger when this behavior is more crystallized, where crystallization refers to the extent of agreement among group members about the level of the behavior in which an individual can appropriately engage (Jackson 1965). A high level of withholding in the group serves as a stronger cue encouraging withholding if more members of the group withhold at or around the same level because there appears to be greater agreement that withholding is acceptable. In contrast, a high level of withholding by group members serves as a weaker cue if some members withhold frequently but others withhold rarely because it is less clear that withholding is generally acceptable among the group members. By increasing the ambiguity surrounding the acceptability of withholding, greater variance reduces the effects of withholding by reference group members on a scientist's conduct. 
HYPOTHESIS 3 (H3). Information withholding by reference group members will have a less positive influence on withholding by a scientist if the group members vary more in their levels of withholding.

Finally, scientists can look to reference groups of status-superiors as well as reference groups of status-equals for normative guidance (Merton 1968, Singer 1981). “Anticipatory socialization,” expressed in conduct appropriate for members of a higher-status group, may increase their chances of joining that group and ease their adjustment once they join (Merton and Rossi 1950: 58). However, the injunctive norms of a group, which refer to what members believe ought to be done, often differ from its descriptive norms, which refer to what the members actually do (Cialdini et al. 1990) —and aspiring group members recognize that status-superiors usually expect them to "do as we say, not as we do" (Siegel and Siegel 1971). It may also be easier to find out about the withholding attitudes of status-superiors than their withholding behaviors, as they are more likely to volunteer information about the former than the latter when asked. Consequently, the attitudes of reference group members who are superior in status to a focal scientist may guide that scientist's withholding decisions more than their behaviors. In contrast, the behaviors of reference group members who are equal in status to a focal scientist are more visible than their attitudes, and more likely to affect that scientist's withholding decisions by capturing attention, causing offense, generating gossip, or triggering competitive responses.

HYPOTHESIS 4a (H4a). The withholding behaviors of reference group members will have more influence than their attitudes on withholding by a scientist if they are the scientist's status-equals.

HYPOTHESIS $4 \mathbf{b}(\mathbf{H} 4 \mathbf{b})$. The withholding attitudes of reference group members will have more influence than their behaviors on withholding by a scientist if they are the scientist's status-superiors.

\section{Influence of Other Reference Group Characteristics}

Our hypotheses focus on the influence of reference groups' withholding cues on information withholding by a focal scientist. However, other reference group characteristics may generate alternative 
explanations for withholding. First, some groups may be more engaged in commercial activities than others, encouraging withholding by group members as well as the focal scientist. For example, some specialties may offer greater opportunities and rewards for commercial activities, or senior faculty may be more engaged in commercial activities than junior faculty. Second, some groups may be more competitive than others, creating perceptions of higher competitiveness that motivate increased withholding by both the group members and the focal scientist. Third, the members of some groups may receive more requests than others due to the nature of their work, again increasing the tendency of both group members and the focal scientist to withhold. Fourth, the members of smaller groups may be more able to detect antisocial behavior and enforce sanctions, discouraging withholding by both group members and the focal scientist. Fifth, specialties may differ in specific characteristics that affect withholding behavior. For instance, the rate of scientific discoveries may be faster in some specialties than in others, creating pressure that motivates both the group members and the focal scientist to withhold information in an effort to maintain a strategic advantage in the race to publication. We examine all these additional group-level explanations in our analyses, as well as the individual-level explanations noted earlier, to establish whether the predicted influence of reference group withholding cues holds after taking them into account.

\section{METHODS}

We tested the hypotheses using quantitative data obtained from a survey of 3,000 geneticists and other life scientists conducted between March and July 2000 by the Center for Survey Research at the University of Massachusetts in Boston. Two focus group discussions, 20 semi-structured interviews, and pretests in nine one-on-one meetings informed the design of the survey. Additionally, we conducted informational interviews with 18 academic scientists, identified through snowball sampling, to develop more in-depth insights into the life sciences community and the professional role expectations of its members. The interviewees included geneticists as well as other life scientists from 12 departments at 5 institutions, who ranged in age from their late-20s to mid-60s and held tenured or non-tenured 
appointments. The interviews lasted one to two hours, and some included laboratory tours and on-site observations. Before describing the quantitative data and analyses, we draw on these informational interviews to offer some qualitative insights into the conflicting role expectations experienced by life scientists and how professional reference groups influence information withholding in this community.

\section{Qualitative Insights}

Conflicting role expectations. The scientists we interviewed reported varying views on information withholding, a term with which they were familiar and that they often invoked proactively. At one end of the spectrum, reflecting the macro view that information sharing is mandated by a fundamental professional norm of communalism, one scientist stated:

I just believe that it's my duty as a scientist to help advance scientific knowledge by sharing what I've learned with others if it can help them, even if there's no personal advantage to me. I think most people feel the same. But, of course, there are always some who don't seem to have had that sense of responsibility so deeply burned into them.

At the other end of the spectrum, consistent with the micro view that information withholding is driven by individual interests, another scientist observed:

Scientific research is so competitive, it's a dog-eat-dog world. Sometimes you have to look out for yourself. No one else will.

More commonly, however, the interviewees reported that decisions about whether to share or withhold information in response to a request from another scientist were often complicated because others' expectations of them as members of the scientific profession created pressures to withhold that conflicted with the dominant norm of sharing.

In particular, they reported feeling that information withholding was necessary to enable them to fulfill the fundamental professional expectation of innovative scholarship (Hagstrom 1965, Sutton 1984). Sharing valuable information with others could compromise their ability to meet this core requirement of their professional role by endangering their research autonomy, inhibiting their freedom to choose what to study, how to study it, and when to publish the findings. As one scientist put it:

My job is to generate and publish original research findings. If I give away data or materials, even from a paper I've already published, I'm going to have more trouble doing my job successfully. 
Another explained why this was a concern:

How likely people are to want to share these things is partly connected to where they are in trying to carry out that work.... There might be future studies there, especially with respect to materials. You might be required by journals to reference particular samples or sequences that you put in the paper. But if someone asks for your whole collection, that's a different matter.

And another scientist echoed a similar theme:

People withhold when they feel like they have a gold mine of information that they might like to use for a long time.... They'll withhold data for a long time because they're waiting to get the very best story and the most credit. They don't want to feel like they're a sucker for having given away all their data. They want to be able to say, "This is my contribution," and get it recognized.

Further, the interviewees indicated that withholding was viewed as a morally regulated role expectation not only because such behavior was reinforced by the promise of professional rewards, but also because violations created risks of sanctions for betraying other members of the profession. Most notably, scientists frequently pointed to an obligation to protect doctoral or postdoctoral students. Sharing information that could compromise the ability of students to publish their work was widely viewed as a violation of a professional responsibility toward dependents. As one scientist commented:

People often explain [withholding] by saying "my graduate student needs to get full credit." I think that's partly an acceptable excuse, but it's also a real reason. There are big investments in collecting data.... More senior people have less riding on a particular data set, but if they give the game away too soon, their students' work could be wrecked.

Withholding was also sometimes viewed as an obligation toward superiors in the profession, not just students. Violation of this expectation could incur the wrath of colleagues, as a junior researcher noted:

In my former lab, I worked on a technology that has the potential to be widely used. The lab had already spent three or four years on it before I got there. It was almost deadlocked. When I got there, I developed a small trick, small but very crucial, that got the project moving again.... It was my turn to present at a joint group meeting with five or six other labs. The PI [principal investigator] was afraid I'd maybe say something I shouldn't [about details of the technology that might enable others to replicate it]. He asked to review the slides. He said, "Don't talk too much about this-don't give too much detail." At the meeting, of course, people wanted to ask me questions. A senior person asked something I thought was completely appropriate for me to answer. But my PI got very angry, even at the meeting. Afterwards he told me to come to his office. We almost fought over this.

These examples illustrate that the academic scientists we interviewed often viewed their professional roles as accompanied by potentially conflicting expectations of information sharing and withholding. Sometimes the decision was obvious, but sometimes it was not. As one scientist succinctly 
observed, "It's often a judgment call." Another articulated the ambivalence that many expressed as follows:

Often, when I get a request, I struggle with whether to just ship out what the person asks for or tell them, "Look, I want to help, but I can't give you this just yet. If you get back to me in a few months, hopefully things will look different." I really want to be a good colleague, but there are good reasons to hold back sometimes. On the other hand, I know it's frustrating to be on the other end when someone won't let you have something you need. I've spent some sleepless nights over this.

How reference group withholding cues influence scientists. For scientists who face such conflicting role expectations, an important requirement for reference group influence is that there are opportunities to learn about the withholding behaviors and attitudes of reference group members. Our interviews indicated that life scientists have many such opportunities because collegial interaction is very high in this professional community. The scientists we interviewed typically participated in frequent professional conferences, consortia, and retreats, estimating that on average they attended four to ten gatherings per year of varying sizes, excluding advisory and peer review committees, study sections at the National Institutes of Health, and other meetings. The laboratory-based research system also generates extensive networks of contacts, as scientists usually run labs in which instructors, post-docs, graduate students, and undergraduates work alongside technicians and administrative staff. The training and socialization process they undergo in the labs generate contacts, and departures to set up new labs leave the former labs with ever-expanding networks of one-time members. Scientists also build and maintain contacts through the extensive collaborations that are typical in the life sciences. Articles are rarely soleauthored, and lists of co-authors can be long; for example, one associate professor who described himself as moderately productive estimated that he had worked with about 10 primary collaborators and more than 30 co-authors during 15 years of publishing. The result of these wide-ranging connections and communication opportunities is that the social environment of the life sciences community provides fertile conditions for reference group influence.

Our interviewees also offered examples of how this influence operates. For instance, indicating that scientists tend to withhold more when their reference groups make this behavior more visible and acceptable, one scientist told us, "I think people feel like it's okay to withhold sometimes when they think 
that everyone else does it too." Another observed, "When I'm not sure what's appropriate to do in a particular situation, I usually try to think about what other people who face the same sort of pressures as me would do," suggesting that reference group members who were more professionally similar to him were those to whom he would naturally look for guidance. The role of variance in withholding behaviors in reference groups was also apparent, as one scientist commented, "If everyone you know does it [withholds] sometimes, it's probably okay to say no occasionally, but if it's just that one cranky guy that everyone talks about who says no to even the most minor things, you probably don't want to be like him." Finally, the influence of status-superiors' attitudes was evident, as illustrated by this quote: "It's important to me to see what people I admire think." The qualitative insights obtained through our interviews thus provide some initial evidence to support the hypotheses that we now test systematically in our quantitative analyses.

\section{Quantitative Data Collection}

The quantitative data used in this study focused primarily on academic geneticists but also covered other academic life scientists (see Campbell et al. 2002). To collect data from a comprehensive sample of geneticists and a random sample of other life scientists at leading U.S. academic institutions, survey recipients were selected by identifying all departments and programs in genetics and human genetics in the 100 U.S. universities that received the most funding from the National Institutes of Health in 1998. Then, up to three additional life science departments and programs at the same universities were randomly selected from lists of clinical departments (medicine, pathology, psychiatry, pediatrics, and surgery) and non-clinical departments (biochemistry, microbiology, pharmacology, physiology, and anatomy) that had received the largest number of NIH grants in 1998. All faculty members in each selected department and program were identified using the Association of American Medical Colleges faculty roster system, Peterson's Graduate Programs in the Biological Sciences, school and individual Web sites, college bulletins, and direct contact with departments. In addition, all faculty members who were principal investigators on at least one research grant from the Human Genome Project (HGP) in the five years preceding the study were identified. The study sample of 3,000 faculty members consisted of 
two strata: faculty members in genetics or human genetics departments $(n=1,766)$ and faculty members from clinical and non-clinical departments $(n=1,234)$. The first stratum included all 219 grantees of the HGP and all 1,547 faculty members in genetics or human genetics departments. The second stratum was randomly selected to include 617 faculty members from non-clinical departments and 617 clinical departments. To avoid including faculty who were not actively engaged in research, the sample excluded clinical department faculty who had no publications in the MEDLINE database in the three years preceding the study.

Of the 3,000 potential respondents, 107 were ineligible for the study because they were retired, out of the country, not located at the sampled institution, not faculty appointments, in the sample twice, or deceased. Of the remaining subjects, 1,849 responded, yielding an overall response rate of $64 \%$. Confidentiality concerns prevented identification of the institutions to which the respondents belonged in the survey, but the research design enabled the identification of non-respondents while ensuring respondent anonymity by asking the respondents to return a postcard separately from the survey. From the list of non-respondents, 256 were interviewed briefly by telephone to determine how they differed from respondents. Non-respondents were less likely to be geneticists, more likely to be full professors, and more likely to receive a high number of requests for information related to their research. In addition to examining the effects of these characteristics on information withholding in our models, we examined whether respondents with and without these characteristics were influenced differently by reference group behaviors and attitudes, and found that they were not, indicating that the exclusion of non-respondents was unlikely to have influenced our results.

\section{Dependent Variable}

The dependent variable was whether a scientist had denied requests for information related to his or her published research. We focused on denials of post-publication requests to maintain consistency with prior research on information withholding by life scientists, which has primarily examined withholding of information related to published research (e.g., Campbell et al. 2002, Walsh et al. 2007). The survey respondents were asked: "In the last three years, about how many times have you received 
requests from other academic scientists for information, data, or materials concerning your published research?" Of the 1,849 respondents, 1,388 reported having received at least one request. Those who reported receiving at least one request were then asked: "In the last three years, how many times have you denied giving other academic scientists requested information, data, or materials related to your published research?" We considered respondents who reported that they had denied at least one request to have engaged in withholding. After restricting the sample to 1,251 respondents who reported having received at least one request and responded to this question, the dependent variable, information withheld, was coded 1 if the respondent reported denying at least one request or 0 otherwise. ${ }^{3}$

\section{Reference Group Withholding Variables}

We examined three levels of professional reference groups for the life scientists in our sample based on field, specialty, and professional status. Although other possible criteria for determining reference groups exist, we selected these for analysis because (a) according to our interviews, they are standard professional dimensions along which life scientists commonly categorize themselves and others, (b) examining these three levels of reference groups enabled us to test the influence of groups of increasing professional similarity to the focal scientist, and (c) the potential to progress from lower to higher status positions enabled us to test the influence of reference groups of status-superiors as well as status-equals.

The first step in constructing the reference group measures was to identify the members of each focal scientist's professional reference groups. To establish the focal scientist's field within the life sciences, the survey respondents were asked to identify themselves as geneticists (coded 1) or others (coded 0), where a geneticist was defined as a scientist "whose research involves any of the following: (1) identification of genomes, genes, or gene products in any organism; (2) study of the structure, function, or regulation of genes or genomes; or (3) comparison of genes and genomes between species and populations." The focal scientist's field-based reference group included all scientists coded 1 if the focal scientist was a geneticist or 0 if a non-geneticist. 
To establish the focal scientist's specialty within the field of genetics, respondents who identified themselves as geneticists were asked to indicate whether they specialized in working with amphibia, bacteria, drosophila, fungi, humans, other mammals, nematodes, plants, viruses, yeast, or zebra fish. A dichotomous variable for each specialty was coded 1 if the geneticist specialized in that organism or 0 otherwise. The focal scientist's specialty-based reference group included all geneticists coded 1 for the same specialty.

To capture the focal scientist's status within his or her specialty in the field of genetics, we examined four status characteristics that carry social significance in the life sciences community according to our interviewees as well as prior research (e.g., Campbell et al. 2002, Owen-Smith 2001). These were academic rank, research experience, research productivity, and research budget. Rank was coded 0 if the respondent reported that he or she was an instructor or lecturer, 1 if an assistant professor, 2 if an associate professor, or 3 if a full professor. Using this measure, we identified reference groups of status-equals as including all geneticists in the same specialty of the same rank, and reference groups of status-superiors as including all geneticists in the same specialty of higher rank. We measured experience by the number of years that the respondent had spent conducting research in the U.S., productivity by the number of articles that the respondent had published in refereed journals in the last three years, and budget by the total fiscal-year research budget in thousands of dollars for all grants, contracts, and projects from all sources on which the respondent was the principal investigator. To identify reference group members based on these criteria, we used moving windows set to three years above and below the focal scientist's experience, three articles more and less than the focal scientist's productivity, and $\$ 150,000$ above and below the scientist's budget, respectively. We identified status-equals as including all geneticists in the same specialty of comparable experience, productivity, or budget (i.e., within the moving windows set by the focal scientist), and status-superiors as all geneticists in the same specialty with greater experience, productivity, or budget (i.e., above the moving windows set by the focal scientist). ${ }^{4}$

The second step in constructing the reference group withholding variables was to calculate the 
withholding behaviors and attitudes in each group and match them to the focal scientist's entry in the data set. ${ }^{5} R G$ w/h level is the average number of times that the members of each group reported withholding information from another scientist who requested it (e.g., $R G$ w/h level [same rank] refers to the level of withholding among reference group members with the same rank as the focal scientist). ${ }^{6} R G w / h$ variance is the standard deviation in the number of times that the members of each group reported withholding information (e.g., $R G w / h$ variance [same rank] refers to the variance in withholding among reference group members with the same rank as the focal scientist). ${ }^{7} R G w / h$ attitudes is the average of the reference group members' responses to the following statement: "Academic scientists should freely share information, data, or materials with all academic scientists" (scale of $1=$ "completely agree," $2=$ "somewhat agree," 3 = "somewhat disagree," or 4 = "completely disagree"), where a higher score indicates more favorable attitudes to withholding in the group (e.g., $R G$ w/h attitudes [higher rank] refers to the attitudes to withholding among reference group members with higher rank than the focal scientist).

\section{Reference Group Control Variables}

To address other possible forms of reference group influence beyond their withholding cues, we included several reference group control variables in our models. $R G$ commercialization is the proportion of members in each reference group who were engaged in commercial activities. $R G$ competition is the average level of perceived competition among the members of each reference group. $R G$ requests received measures the average number of requests received by the members of each reference group. $R G$ size is captured by the number of members in the reference group. The sizes of the reference groups varied according to their type-field, specialty, and professional status. The field-based reference groups consisted of 904 geneticists and 347 non-geneticists. The eleven specialty-based reference groups included 70.55 scientists on average, ranging from 7 (zebra fish) to 231 (mammals). The average size of the status-based reference groups was 30.83 (rank), 49.83 (experience), 23.85 (productivity), and 31.70 (budget). ${ }^{8}$ We also used dichotomous variables for each specialty to control for any other unobserved differences across specialties that might lead to higher withholding by both members and the focal scientist, such as variation in discovery rates. ${ }^{9}$ 


\section{Individual Control Variables}

To address individual explanations for information withholding in our models, we first included the individual-level variables that prior research has found to significantly predict withholding: receiving more requests, engaging in commercial activities, receiving industry support, conducting research using human subjects, and being male (Campbell et al. 2002). We followed the prior research in coding these as

dichotomous variables. ${ }^{10}$ Requests received was coded 1 if the respondent received more than six requests for data, information, or materials regarding his or her publications from other academic scientists during the last three years or 0 if the respondent received one to six requests. Commercial activities was coded 1 if the respondent answered "yes" to any of the following questions about engagement in commercial activities or 0 otherwise: "In the last three years has the research that you do at your university resulted in (a) patents applied for, (b) patents issued, (c) patents licensed, (d) a product under regulatory review, (e) a product on the market, (f) a start-up company?" Industry support was coded 1 if the respondent had received research grants or contracts from companies whose work was related to his or her area of scientific expertise in the last three years or 0 otherwise. Human subjects was coded 1 if the respondent reported conducting research that involved living humans as research subjects in the last three years or 0 if not. Male was coded 1 if the respondent was male or 0 if female.

Second, we included additional individual-level variables that prior research or our interviews suggested could motivate information withholding in the life sciences context. Own requests denied captures whether the respondent had had his or her own requests denied by another academic scientist in the last three years ( 1 if one or more requests were denied or 0 otherwise). Mentor withholding captures the influence of mentors by averaging the responses to two questions: "When you were in (a) predoctoral (b) postdoctoral training, how willing were your lab directors/mentors to share their research information, data, or materials with other academic scientists?" (1 = "very," 2 = "somewhat," 3 = "not very," or $4=$ "not at all"). Perceived competition measures how a scientist perceived the overall level of competition in his or her area using the following question: "How would you characterize the overall level of 
competition for recognition or scientific priority in your specific area of research?" $(1=$ "not at all competitive," 2 = "not very competitive," 3 = "moderately competitive," or 4 = "very competitive").

Finally, we also examined individual-level variables that corresponded to the professional characteristics used to construct the reference group withholding variables described above: the focal scientist's field, specialty, rank, experience, productivity, and budget. We also included the scientist's attitude to withholding as a control variable in the models that examined reference group attitudes.

\section{RESULTS}

The 1,849 life scientists who responded to the survey reported receiving a total of 35,601 requests in the last three years from other academic scientists for information, data, or materials concerning their published research, an average of 19 requests per scientist. The percentage of scientists in the sample who reported denying at least one such request was $10.9 \%$, and those who withheld information denied an average of $9.7 \%$ of requests received. ${ }^{11}$ Table 1 reports descriptive statistics and correlations for the variables shown in the models. In the subsequent tables, we report the results of logistic analyses predicting the likelihood that a scientist engaged in information withholding.

----- insert Table 1 about here -----

\section{Effects of Control Variables}

The models in Tables 2, 3, and 4 present the results for the hypotheses as well as the individual and reference group control variables. We discuss the control variables first. Model 1 in Table 2 includes the full sample of 1,251 geneticists and non-geneticists who received at least one request for information. Replicating prior research on individual-level predictors of withholding (Campbell et al. 2002), this model shows that these life scientists were more likely to withhold if they received more requests, engaged in commercial activities, used human subjects in their research, and were male, though industry support was not associated with withholding in this model or any others. Scientists were also more likely to withhold if they had had requests of their own denied and mentors who were less willing to share information, but the effect of perceived competition was not significant. All subsequent models focus on 
the sample of 904 geneticists only. These models show that geneticists were more likely to withhold information if they engaged in commercial activities, were male, reported higher perceived competition in their areas, and had more favorable attitudes to withholding. All these models also include the group-level controls for reference group size, commercialization, competition, and requests received; these are consistently non-significant.

In additional analyses (not shown), we also addressed whether scientists' individual specialties, rank, experience, productivity, or budgets influenced the likelihood of information withholding by examining the effects of these individual-level variables. The results indicated that compared to those who specialized in humans, those who specialized in mammals, viruses, or yeast were less likely to withhold ( $\mathrm{p}<0.05, \mathrm{p}<0.01$, and $\mathrm{p}<0.10$ respectively). However, excluding the individual specialty variables from the models did not affect our main results. We detected no significant main effects of individual rank, experience, productivity, or budget; no curvilinear effects of these four variables; and no other non-linear effects by using categorical measures instead of continuous measures. We further examined the effects of interactions between the individual-level variables on withholding behavior (e.g., rank and commercial activities), but found no significant results.

----- insert Table 2 about here -----

\section{Effects of Levels of Information Withholding in Reference Groups (H1)}

$\mathrm{H} 1$ predicted that information withholding in a reference group will have a positive influence on withholding by a focal scientist. Model 1 in Table 2, which includes the full sample of life scientists, shows that more withholding in reference groups composed of all others in the same field (i.e., geneticists or non-geneticists) is not significantly associated with a higher probability of withholding by a focal scientist. However, Model 2, which focuses on the sample of geneticists only, indicates that more withholding in groups composed of other geneticists with the same specialty does have a significant positive effect, providing initial evidence to support H1. Models 3-6 examine the effects of withholding in reference groups composed of geneticists with the same specialty who also shared the same rank, experience, productivity, or budget as the focal scientist. These models provide further support for H1, as 
there is a significant positive association between the level of withholding in the reference group and a focal scientist's withholding behavior for each of the four status-based reference groups.

\section{Effects of Information Withholding in More Professionally Similar Reference Groups (H2)}

$\mathrm{H} 2$ predicted that the influence of information withholding in a reference group will be stronger if the group members are more professionally similar to the focal scientist. Comparing Model 2 to Model 1

in Table 2 provides initial evidence to support this hypothesis, as groups composed of geneticists with the same specialty had a more significant positive effect on withholding by the focal scientist than groups composed of all geneticists, and the improvement in model fit from including the reference group withholding variable is correspondingly greater for Model 2 than for Model 1. Comparing Models 3-6 to Model 2 provides further support for $\mathrm{H} 2$, as the effects of groups composed of geneticists with the same specialty who were also similar in status were more significant than the effects of groups composed of geneticists with the same specialty of any status, and the improvements in model fit from including the reference group variables are greater for Models 3-6 than for Model 2. The models thus support H2.

\section{Effects of Variance in Information Withholding in Reference Groups (H3)}

Models 1-8 in Table 3 show the results for H3, which predicted that the influence of information withholding by reference group members will be weaker if the group members vary more in their level of withholding. To test this hypothesis, we examined interactions between the (mean-centered) level and variance of withholding in the most professionally similar reference groups (i.e., geneticists with the same specialty who also shared the same rank, experience, productivity, or budget as the focal scientist). The models show that for all four types of status-based reference groups, the positive association between withholding by reference group members and withholding by a focal scientist is lower when there is more variance around those higher levels of withholding. These results provide support for H3.

----- insert Table 3 about here -----

\section{Effects of Behaviors v. Attitudes in Reference Groups of Status-Equals v. Status-Superiors (H4)}

H4a predicted that withholding is influenced more by the behaviors than the attitudes of statusequals. As reported earlier, Models 3-6 in Table 2 show significant effects of withholding behaviors in 
reference groups composed of members with the same rank, experience, productivity, and budget as the focal scientist. In comparable models not shown here, we examined the effects of withholding attitudes in these reference groups. The results revealed no significant effects of withholding attitudes in groups with same rank, productivity, or budget $(b=0.21,0.09$, and 0.55 , respectively; all $p>0.10)$, although more favorable attitudes to withholding among the members of reference groups with the same experience were associated with a higher likelihood of withholding by the focal scientist $(b=4.95, p<0.01)$. With the exception of this one finding, these results provide support for $\mathrm{H} 4 \mathrm{a}$.

H4b predicted that withholding is influenced more by the attitudes than the behaviors of statussuperiors. In Models 1-4 in Table 4, we show the effects of withholding attitudes in reference groups composed of members with higher rank, experience, productivity, or budgets than the focal scientist. The results reveal that more favorable attitudes to withholding among scientists in all four of these reference groups were significantly associated with a higher likelihood of withholding by the focal scientist. In contrast, in comparable models not shown here, we examined the effects of withholding behaviors in reference groups composed of members with higher rank, experience, productivity, or budgets than the focal scientist and found no significant effects of the behaviors of these status-superiors $(b=-0.51,0.47$, 0.51 , and 0.20 , respectively; all $\mathrm{p}>0.10$ ). Taken together, these findings provide support for $\mathrm{H} 4 \mathrm{~b}$.

----- insert Table 4 about here -----

Finally, in supplementary analyses, we tested whether the reference group withholding variables were moderated by the individual control variables that predicted withholding in our models. The purpose of these analyses was to see whether withholding behavior in reference groups was more strongly associated with information withholding by scientists whose individual characteristics predisposed them to withhold. The results revealed no significant positive interactions, however, and a significant negative interaction between the level of withholding among scientists of the same rank and the focal scientist's perceptions of competition $(b=-5.28, p<0.05)$, indicating that withholding by those of the same rank increased the likelihood of withholding by scientists who were less rather than more individually inclined to withhold. We also examined interactions between the reference group withholding variables and the 
reference group control variables, for example to see whether the effects of withholding in the reference group varied with the size of the group, but found no significant effects.

\section{DISCUSSION}

The main finding of this study is that information withholding among scientists cannot simply be explained by the rejection of professional norms in favor of individual interests. Instead, scientists often look to reference groups within the scientific profession to guide their behavior, indicating that they still value professional norms, though at a meso rather than macro level. The study revealed that information withholding by life scientists was influenced by withholding among members of their reference groups, especially when those members were more professionally similar to the scientist in their field, specialty, and status, and when their behaviors converged more. Scientists were influenced by professional reference groups composed of members who were superior as well as equal in status to themselves, but the withholding behaviors of status-equals were generally more influential than their attitudes, whereas the withholding attitudes of status-superiors were more influential than their behaviors.

\section{Theoretical Implications}

Sociological theories of professions have long recognized that conflicting expectations create tension at the boundaries of professions, where pressures are often imposed by encroaching occupations or by heteronomous administrative structures that subordinate professional work to non-professional bureaucratic goals (e.g., Scott 1965, Abbott 1988). Yet conflicting expectations exist and generate tensions not only at the boundaries of professions but also within them, imposing contradictory demands on members of the profession. In this study, we have argued that scientists face conflicting expectations of information sharing versus withholding. Prior research has similarly argued that scientists experience pressures to be both passionate and intellectually neutral about their research (Mitroff 1974), as well as to claim originality while preserving humility (Merton 1963). However, conflicting expectations are not limited to the academic physical or life sciences. For instance, physicians are expected to be compassionate but emotionally detached from their patients (Merton and Barber 1963), and accountants 
should maintain good client relations yet resist pressures to report their finances in a favorable light (Sorensen and Sorensen 1974). This pervasiveness of competing role expectations in many professions renders efforts to resolve sociological ambivalence central to understanding professional conduct well beyond the scientific domain.

A reference group perspective on professional conduct avoids the extremes of an over-socialized perspective, where norms are viewed as iron-cage constraints on action (cf. DiMaggio and Powell 1983) and an under-socialized perspective, where norms are viewed as irrelevant in the face of individual interests (cf. Granovetter 1985). Instead, norms are viewed here as locally embodied and enacted (cf. Dacin et al. 2002, Thornton and Ocasio 2008). This view is consistent with ethnographic studies in the sociology of science that draw attention to the everyday processes through which small groups locally adapt global professional norms, such as organized skepticism, in the daily work of scientific laboratories (e.g., Owen-Smith 2001). By highlighting the influence of professional reference groups on scientists' conduct, our perspective thus offers a meso-level explanation for withholding behavior that contrasts with the prevailing view that such behavior occurs when micro-level individual interests lead scientists to reject a macro-level norm of communalism.

Our arguments about reference group influence suggest that cues from group members genuinely guide scientists' professional conduct by helping them to resolve sociological ambivalence. An alternative argument suggested by the sociology of science, however, is that reference group cues may be little more than mere rhetorical resources that are useful for justifying strategic behavior by self-interested individuals (cf. Mulkay 1969, Sismondo 2004). To address this possibility, in our supplementary analyses we examined whether reference group cues might be more readily followed by scientists who were more individually inclined to withhold. As reported in the results section, we found no evidence for this, indicating that our claims about reference group influence are robust to this alternative view of how reference group cues relate to individuals' withholding decisions.

Although this study focuses on information withholding in the scientific profession, it also offers implications for theory and research on intra-organizational learning and knowledge transfer, responding 
to calls for further insight into the mechanisms underlying these critical organizational processes (e.g., Argote and Ophir 2002). Prior studies have shown that social network ties and electronic communication technologies facilitate information exchanges (e.g., Sproull and Kiesler 1991, Reagans and McEvily 2003). The implication is that withholding occurs because barriers to sharing impede the ability to exchange information easily, yet individuals often resist sharing even if such barriers are minimized (Cabrera and Cabrera 2002), indicating that willingness as well as ability to share matters. Resistance to information sharing is often explained by the relationship between the parties to the potential exchange, including efforts to exert control over others in politicized environments (Feldman 1988), lack of trust or status distance between the exchange partners (Levin and Cross 2004, Phillips et al. 2009), low psychological safety in work groups (Edmondson 1999), or competition within and across firms (Larsson et al. 1998, Hansen et al. 2005). The present study similarly emphasizes willingness rather than ability to share (Quigley et al. 2007), but extends prior research by drawing attention to the importance of social context beyond the immediate parties to the exchange in influencing sharing decisions. In particular, members of a reference group can influence the sharing decisions of others who do belong to the same group or even interact with them.

More broadly, by highlighting the role of normative expectations, this study also illuminates the cultural issues that contribute to problems of knowledge sharing in organizations. If an organization has a "culture of hoarding" (Boisot 1998), withholding is likely to be pervasive, no matter what structural barriers to sharing are eliminated. Even in an organization with a strong firm-wide culture committed to knowledge sharing and incentives in place to support it, local counter-cultures of withholding in particular offices or work groups can be very influential for their members (Quigley et al. 2007). The findings of our study suggest that the mechanisms that explain intra-organizational learning derive not only from individual characteristics and structural conditions that inhibit knowledge sharing, but also from the norms of the groups in which individuals, teams, and organizations are embedded. For practitioners concerned with implementing "knowledge management" initiatives, the pervasive influence of such norms can help to explain why investments in sophisticated technologies and efforts to motivate 
organization members to codify and share their expertise so often run into resistance and yield fewer benefits than anticipated (Cabrera and Cabrera 2002).

Finally, the theoretical perspective developed in this paper suggests that dysfunctional learning may occur as organization members look to cues from salient reference groups in the face of conflicting role expectations. For example, corporate accounting scandals are typically attributed to the normbreaking behaviors of a handful of rogue individuals, at least officially, but an alternative explanation is that in high-pressure corporate environments, a counter-norm of "winning at any cost" may exist in conflict with the dominant norm of "winning fairly." Organization members might come to view either standard as consistent with the collective interests of the organization, and hence appropriate to their roles as committed members. In such situations, the attitudes and behaviors of reference groups within the organization may powerfully encourage (or discourage) organizational misconduct (Vaughan 1999).

\section{Future Directions}

Our findings support our arguments that reference group cues help to guide professional conduct. However, scientists may also be affected by cues from other sources. For example, prior research has shown that both spatial proximity (institutions) and social proximity (co-author networks) affect the likelihood that an academic scientist will become an entrepreneur (Stuart and Ding 2006, Bercovitz and Feldman 2007). We cannot separate these effects from reference group influence in this study because the anonymity of the survey respondents prevented identification of their institutional affiliations or interpersonal networks. Still, our sample and measures strongly suggest that the reference groups we studied exerted influence on withholding behavior beyond spatial and social proximity effects. First, our data set included 1,251 scientists from 100 universities, giving an average of only 12.5 respondents per institution, who were spread across genetics, clinical, and non-clinical departments and then further divided by specialty and status characteristics within those departments. The small size of the resulting subgroups of comparable scientists at the same institution relative to the reference groups studied here suggests that spatial proximity is unlikely to account for the reference group effects we identified. Second, our findings of reference group effects were robust across multiple groups defined by a range of 
professional characteristics, indicating that salient cues are not limited to a small set of personal contacts such as co-author networks. Additionally, our findings demonstrated the influence of reference groups to which the scientist did not belong (status-superiors) as well as those to which they did (status-equals), further suggesting that networks are not the only source of salient cues for scientists. Nevertheless, it is very likely that reference groups, institutions, and networks all play roles in influencing professional conduct, and future research could usefully distinguish their relative importance.

As noted earlier, we used an etic approach to identify reference groups based on observerdefined criteria. An alternative approach would be to ascertain a set of reference individuals by relying on participants' self-reports to identify those whom they know or interact with (e.g., Zabusky and Barley 1997). Such an emic approach has its own drawbacks, however, including essentially arbitrary limitations on the number of group members which may distort the results, as well as the difficulty of ensuring robustness across reference groups or common professional characteristics among the group members (Lawrence 2006). It can also be argued that our etic approach provides a more conservative test for reference group effects because the influence of observer-defined reference groups is likely to be weaker than the influence of participant-defined reference groups that are clearly salient for the participants by empirical design. Still, confirming the importance of reference group influence using an emic approach would be valuable.

Another direction for future research would be to explore the relationship between the two parties to the potential exchange, as this may directly influence whether targets of requests decide to share their information. We might expect scientists to be more responsive to requests from others who have helped them in the past, for example, and status-inferiors to be more responsive to requests from status-superiors than vice versa. Future research could also investigate exactly what, when, and how scientists choose to share or to withhold in response to specific requests. Hilgartner and Brandt-Rauf (1994) suggested that scientific information is embedded in evolving data streams composed of heterogeneous collections of entities; some portions of a data stream may be well established, whereas others may be of uncertain reliability, and some requests are minor, whereas others are of considerable magnitude. Further, some 
types of information may be inherently more difficult to transfer than others (Walsh et al. 2007). The implication is that decisions about information sharing often become questions of what exactly to disseminate, with whom and when, and by what means. These realities of sharing decisions in the scientific profession parallel the challenges in many organizational settings and call for additional investigation into the possibility that different norms and counter-norms might govern different types of sharing in specific contexts.

\section{Conclusion}

Information sharing is critical to the advancement of the scientific knowledge on which so many organizations and industries depend for innovation, growth, and competitive advantage in the global economy. Despite widespread recognition of this imperative, however, information withholding is not uncommon in the scientific profession, as in organizations. Greater understanding of the meso-level uniformities underlying patterns of information withholding can offer insight into the causes of this behavior among scientists, and advance our understanding of the conditions under which individuals decide to withhold rather than share information in professional as well as organizational settings. 


\section{REFERENCES}

Abbott, A. 1981. Status and status strain in the professions. Amer. J. Sociol. 86 819-835.

Abbott, A. 1988. The System of Professions: An Essay on the Division of Expert Labor. University of Chicago Press, Chicago, IL.

Almeida, P., B. Kogut. 1999. Localization of knowledge and the mobility of engineers in regional networks. Management Sci. 45 905-917.

Argote, L., R. Ophir. 2002. Intraorganizational learning. J. A. C. Baum, eds. Companion to Organizations. Blackwell, Malden, MA, 181-207.

Argyres, N. S., J. P. Liebeskind. 1998. Privatizing the intellectual commons: Universities and the commercialization of biotechnology. J. Econom. Behav. Organ. 35 427-454.

Bamberger, P., M. Biron. 2007. Group norms and excessive absenteeism: The role of peer referent others. Organ. Behavior and Human Decision Processes 103 179-196.

Bercovitz, J., M. Feldman. 2007. Academic entrepreneurs: Who participates and why? F. Malerba, S. Brusoni, eds. Perspectives on Innovation. Cambridge University Press, New York, 381-398.

Berger, J., S. J. Rosenholtz, M. Zelditch. 1980. Status organizing processes. Annual Rev. Sociol. 6 479508.

Bierly, P., A. Chakrabarti. 1996. Generic knowledge strategies in the U.S. pharmaceutical industry. Strategic Management J. 17 123-134.

Blumenthal, D., E. G. Campbell, M. Gokhale, R. Yucel, B. Clarridge, S. Hilgartner, N. Holtzman, T. G. Ferris. 2006. Data withholding in genetics and the other life sciences: Prevalences and predictors. Academic Medicine 81 137-145.

Blumenthal, D., E. G. Campbell, M. S. Anderson, N. Causino, K. S. Louis. 1997. Withholding research results in academic life science: Evidence from a national survey of faculty. J. Amer. Medical Association 277 1224-1228.

Boisot, M. 1998. Knowledge Assets, Securing Competitive Advantage in the Information Economy. Oxford University Press, Oxford.

Bok, S. 1982. Secrets: On the Ethics of Concealment and Revelation. Pantheon Books, New York.

Brown, J. S., P. Duguid. 1991. Organizational learning and communities-of-practice: Toward a unified view of working, learning, and innovating. Organ. Sci. 2 40-57.

Burt, R., M. Knez. 1996. Trust and third-party gossip. R. M. Kramer, T. R. Tyler, eds. Trust in Organizations: Frontiers of Theory and Research. Sage, Thousand Oaks, CA, 68-89.

Cabrera, A., E. F. Cabrera. 2002. Knowledge-sharing dilemmas. Organ. Stud. 23 687-710.

Campbell, E. G., B. R. Clarridge, M. Gokhale, L. Birenbaum, S. Hilgartner, N. A. Holtzman, D. Blumenthal. 2002. Data withholding in academic genetics: Evidence from a national survey. J. Amer. Medical Association 287 473-480.

Cialdini, R. B., R. R. Reno, C. A. Kallgren. 1990. A focus theory of normative conduct: Recycling the concept of norms to reduce littering in public places. J. Personality Soc. Psych. 58 1015-1026.

Cohen, W. M., R. R. Nelson, J. P. Walsh. 2000. Links and impact: The influence of public research on 
industrial R\&D. Management Sci. 48 1-23.

Cook-Deegan, R. M., S. J. McCormack. 2001. Intellectual property: Patents, secrecy, and DNA. Science 293, 217.

Dacin, M. T., J. Goodstein, W. R. Scott. 2002. Institutional theory and institutional change: Introduction to the special research forum. Acad. Management J. 45 45-57.

DiMaggio, P. J., W. W. Powell. 1983. The iron cage revisited: Institutional isomorphism and collective rationality in organizational fields. Amer. Sociol. Rev. 48 147-160.

Edmondson, A. C. 1996. Learning from mistakes is easier said than done: Group and organizational influences on the detection and correction of human error. J. Appl. Behav. Sci. 32 5-28.

Edmondson, A. C. 1999. Psychological safety and learning behavior in work teams. Admin. Sci. Quart. 44 350-383.

Etzkowitz, H. 1989. Entrepreneurial science in the academy: A case of the transformation of norms. Soc. Problems 36 14-29.

Feldman, S. P. 1988. Secrecy, information, and politics: an essay on organizational decision making. Human Relations 41 73-90.

Festinger, L. 1954. A theory of social comparison processes. Human Relations 7 117-140.

Fowler, F. J. 1993. Survey Research Methods. Newbury Park, CA: Sage Publications.

Flynn, F. 2005. Identity orientations and forms of social exchange in organizations. Acad. Management Rev. 30 737-750.

Freidson, E. 2001. Professionalism: The Third Logic. University of Chicago, Chicago, IL.

Goode, W. J. 1957. Community within a community: The professions. Amer. Sociol. Rev., 22: 194-200.

Goodman, P. S. 1974. An examination of the referents used in the evaluation of pay. Organ. Behav. Human Performance 12 170-195.

Granovetter, M. 1985. Economic action and social structure: The problem of embeddedness. Amer. J. Sociol. 91: 481-510.

Hagstrom, W. O. 1965. The Academic Community. Basic Books, New York.

Hansen, M. T., M. L. Mors, B. Løvås. 2005. Knowledge sharing in organizations: Multiple networks, multiple phases. Acad. Management J. 48 776-793.

Hilgartner, S., S. I. Brandt-Rauf. 1994. Data access, ownership, and control: Toward empirical studies of access practices. Knowledge: Creation, Diffusion, Utilization 15 355-372.

Hyman, H., E. Singer. 1968. Readings in Reference Group Theory and Research. Free Press, New York.

Ibarra, H. 1992. Homophily and differential returns: Sex differences in network structure and access in an advertising firm. Admin. Sci. Quart. 37 422-447.

Jackson, J. 1965. Social stratification, social norms, and roles. I. D. Steiner, M. Fishbein, eds. Current Studies in Social Psychology. Holt, Rinhart, \& Winston, New York, 301-309.

Jansen, E., M. Glinow. 1985. Ethical ambivalence and organizational reward systems. Acad. Management Rev. $10814-822$. 
Kidwell, R. E., N. Bennett. 1993. Employee propensity to withhold effort: a conceptual model to intersect three avenues of research. Acad. Management Rev. 18 429-456.

Knorr-Cetina, K. 1982. Scientific communities or transepistemic arenas of research? A critique of quasieconomic models of science. Soc. Stud. Sci. 12 101-30.

Knorr-Cetina, K. 1999. Epistemic Cultures: How the Sciences Make Knowledge. Harvard University Press, Cambridge, MA.

Larsson, R., L. Bengtsson, K. Henriksson, J. Sparks. 1998. The interorganizational learning dilemma: Collective knowledge development in strategic alliances. Organ. Sci. 9 285-305.

Lawrence, B. S. 2006. Organizational reference groups: A missing perspective on social context. Organ. Sci. $1780-100$.

Lazarsfeld, P. F., R. K. Merton. 1954. Friendship as a social process: A substantive and methodological analysis. In M. Berger, T. Abel, C. H. Page, eds. Freedom and Control in Modern Society. Van Nostrand, New York, 18-66.

Leicht, K. T., M. L. Fennell. 2001. Professional Work: A Sociological Approach. Blackwell, Malden, MA.

Levin, D. Z., R. Cross. 2004. The strength of weak ties you can trust: The mediating role of trust in effective knowledge transfer. Management Sci. 50 1477-1490.

Liebeskind, J. P., A. L. Oliver, L. Zucker, M. Brewer. 1996. Social networks, learning, and flexibility: Sourcing scientific knowledge in new biotechnology firms. Organ. Sci. 7 428-443.

Louis, K. S., D. Blumenthal, M. E. Gluck, M. A. Stoto. 1989. Entrepreneurs in Academe: An exploration of behaviors among life scientists. Admin. Sci. Quart. 34 110-131.

Louis, K. S., L. M. Jones, M. S. Anderson, D. Blumenthal, E. G. Campbell. 2001. Entrepreneurship, secrecy, and productivity: A comparison of clinical and non-clinical life sciences faculty. J. Tech. Transfer 26 233-245.

Manski, C. F. 1993. Identification of endogenous social effects: The reflection problem. Rev. Econom. Stud. 60 531-542.

Marsden, P. V., N. E. Friedkin. 1993. Network studies of social influence. Soc. Methods Res. 22 127-151.

McCain, K. W. 1991. Communication, competition, and secrecy: The production and dissemination of research-related information in genetics. Sci. Tech. Human Values 16 491-516.

Merton, R. K. 1963. The ambivalence of scientists. Bull. Johns Hopkins Hospital 112 77-97.

Merton, R. K. 1968. Continuities in the theory of reference groups and social structure. R. K. Merton, ed. Social Theory and Social Structure. Free Press, New York, 335-440.

Merton, R. K. 1973 (1942). The normative structure of science. R. K. Merton, ed. The Sociology of Science: Theoretical and Empirical Investigations. University of Chicago Press, Chicago, 267-278.

Merton, R. K. 1976. Sociological Ambivalence. The Free Press, New York.

Merton, R. K., A. S. Rossi 1950. Contributions to the theory of reference group behavior. R. K. Merton, P. F. Lazarsfeld, eds. Continuities in Social Research. The Free Press, New York, 40-105.

Merton. R. K., E. Barber. 1963. Sociological ambivalence. E. A. Tiryakian, ed. Sociological Theory, Values, and Socio-cultural Change. The Free Press, New York, 91-120.

Merton. R. K., G. George, P. L. Kendall. 1957. The Student-Physician: Introductory Studies in the 
Sociology of Medical Education. Harvard University Press, Cambridge, MA.

Mills, E. W. 1983 Sociological ambivalence and social order: The constructive uses of normative dissonance. Sociol. Soc. Res. 67 279-287.

Mitroff, I. 1974. Norms and counter-norms in a select group of the Apollo moon scientists: A case study of the ambivalence of scientists. Amer. Sociol. Rev. 39 579-595.

Mulkay, M. J. 1969. Some aspects of cultural growth in the sciences. Soc. Res. 36 22-52.

Murray, F. 2004. The role of academic inventors in entrepreneurial firms: Sharing the laboratory life. Res. Policy 33 643-659.

Murray, F., S. Stern. 2007. Do formal intellectual property rights hinder the free flow of scientific knowledge? An empirical test of the anti-commons hypothesis. J. Econom. Behav. Organ. 63 648687.

National Research Council. 2003. Sharing Publication-Related Data and Materials: Responsibilities of Authorship in the Life Sciences. National Academies Press, Washington, DC.

Nelkin, D. 1984. Science as Intellectual Property: Who Controls Research? MacMillan, New York.

Owen-Smith, J. 2001. Managing laboratory work through skepticism: Processes of evaluation and control. Amer. Sociol. Rev. 66 427-452.

Owen-Smith, J., W. W. Powell. 2004. Knowledge networks as channels and conduits: The effects of spillovers in the Boston biotechnology community. Organ. Sci. 15 5-21.

Pavalko, R. M. 1988. Sociology of Occupations and Professions, 2nd ed. Peacock, Itasca, IL.

Phillips, K. W., N. P. Rothbard, T. L. Dumas. 2009. To disclose or not to disclose? Status distance and self-disclosure in diverse environments. Acad. Management Rev. 34: 710-732.

Polanyi, M. 1962. The republic of science: Its political and economic theory. Minerva 1 54-74.

Pratt, M. G. 2000. The good, the bad, and the ambivalent: Managing identification among Amway distributors. Admin. Sci. Quart. 45 456-493.

Quigley, N. R., P. E. Tesluk, E. A. Locke, K. M. Bartol. 2007. A multilevel investigation of the motivational mechanisms underlying knowledge sharing and performance. Organ. Sci. 18 71-88.

Reagans, R., B. McEvily. 2003. Network structure and knowledge transfer: The effects of cohesion and range. Admin. Sci. Quart. 48 240-267.

Scott, W. R. 1965. Reactions to supervision in a heteronomous professional organization. Admin. Sci. Quart. 10 65-81.

Siegel, A. E., S. Siegel. 1971. Reference groups, membership groups, and attitude change. In A. Doob, D. T. Regan, eds. Readings in Experimental Social Psychology. Appleton-Century-Crofts, New York, 391-398.

Singer, E. 1981. Reference groups and social evaluation. M. Rosenberg, R. H. Turner, eds. Social Psychology and Sociological Perspectives. Transaction, New Brunswick, NH, 66-93.

Singh, P. 1994. Perception and reactions to inequity as a function of social comparison referents and hierarchical levels. J. Appl. Soc. Psych. 24 557-565.

Sismondo, S. 2004. An Introduction to Science and Technology Studies. Blackwell, Malden, MA. 
Smelser, N. J. 1998. The rational and the ambivalent in the social sciences: 1997 Presidential Address. Amer. Sociol. Rev. 63 1-16.

Sorensen, J. B. 2002. The use and misuse of the coefficient of variation in organizational demography research. Soc. Methods Res. 30 475-491.

Sorensen, J. E., T. L. Sorensen. 1974. The conflict of professionals in bureaucratic organizations. Admin. Sci. Quart. 19 98-106.

Sproull, L., S. Kiesler. 1991. Connections. MIT Press, Cambridge.

Strang, D., J. W. Meyer. 1993. Institutional conditions for diffusion. Theory Soc. 22 487-511.

Stuart, T. E., W. W. Ding. 2006. When do scientists become entrepreneurs? The social structural antecedents of commercial activity in the academic life sciences. Amer. J. Sociol. 112 97-144.

Sutton, J. R. 1984. Organizational autonomy and professional norms in science: A case study of the Lawrence Livermore Laboratory. Soc. Stud. Sci. 14 197-224.

Szulanski, G. 1996. Exploring internal stickiness: Impediments to the transfer of best practice within the firm. Strategic Management J. 17 27-43.

Terry, D. J., M. A. Hogg, J. M. Duck. 1999. Group membership, social identity, and attitudes. D. Abrams, M. A. Hogg, eds. Social Identity and Social Cognition. Blackwell, Oxford, UK, 280-314.

Thornton, P. H., W. Ocasio. 2008. Institutional logics. R. Greenwook, C. Oliver, R. Suddaby, K. Sahlin, eds. Organizational Institutionalism. Sage, Los Angeles, 99-129.

Walsh, J. P., W. Hong. 2003. Secrecy is increasing in step with competition. Nature 422 801-802.

Walsh, J. P., W. M. Cohen, C. Cho. 2007. Where excludability matters: Material versus intellectual property in academic biomedical research. Res. Policy 36 1184-1203.

Webster, M., S. Hysom. 1998. Creating status characteristics. Amer. Sociol. Rev. 63 351-378.

Wilensky, H. L. 1964. The professionalization of everyone? Amer. J. Sociol. 70 137-158.

Vaughan, D. 1999. The dark side of organizations: Mistake, misconduct, and disaster. Annual Rev. Sociol. 25 271- 305.

Zabusky, S. E., S. R. Barley. 1997. You can't be a stone if you're cement: Reevaluating the emic identities of scientists in organizations. Research in Organizational Behavior, Vol. 19. JAI Press, Greenwich, CT, 361-404. 
Table 1. Descriptive statistics and correlations

\begin{tabular}{|c|c|c|c|c|c|c|c|c|c|c|c|c|c|c|c|c|c|}
\hline & Variable & Mean & S.D. & Min & Max & 1 & 2 & 3 & 4 & 5 & 6 & 7 & 8 & 9 & 10 & 11 & 12 \\
\hline & Dependent variable & & & & & & & & & & & & & & & & \\
\hline 1 & $\begin{array}{l}\text { Information withheld } \\
\text { Individual control variables }\end{array}$ & 0.11 & 0.31 & 0 & 1 & & & & & & & & & & & & \\
\hline 2 & Requests received & 0.55 & 0.50 & 0 & 1 & 0.09 & & & & & & & & & & & \\
\hline 3 & Commercial activities & 0.33 & 0.47 & 0 & 1 & 0.11 & 0.13 & & & & & & & & & & \\
\hline 4 & Industry support & 0.67 & 0.47 & 0 & 1 & 0.06 & 0.02 & 0.18 & & & & & & & & & \\
\hline 5 & Human subjects & 0.33 & 0.47 & 0 & 1 & 0.06 & -0.15 & 0.06 & 0.10 & & & & & & & & \\
\hline 6 & Male & 0.75 & 0.43 & 0 & 1 & 0.05 & 0.03 & 0.10 & -0.02 & -0.04 & & & & & & & \\
\hline 7 & Own requests denied & 0.37 & 0.48 & 0 & 1 & 0.09 & 0.13 & 0.11 & 0.09 & -0.06 & -0.01 & & & & & & \\
\hline 8 & Perceived competition & 3.59 & 0.57 & 1 & 4 & 0.06 & 0.07 & 0.12 & 0.10 & -0.04 & 0.03 & 0.15 & & & & & \\
\hline 9 & $\begin{array}{l}\text { Mentor withholding } \\
\text { Reference group control variables }\end{array}$ & 1.60 & 0.62 & 1 & 4 & 0.07 & -0.07 & 0.00 & 0.01 & 0.05 & -0.06 & 0.08 & 0.04 & & & & \\
\hline 10 & RG size & 155.55 & 77.68 & 56 & 279.67 & 0.07 & 0.18 & 0.10 & 0.07 & -0.11 & -0.03 & 0.19 & 0.15 & -0.02 & & & \\
\hline 11 & RG commercialization & 0.33 & 0.08 & 0.18 & 0.68 & 0.10 & 0.14 & 0.32 & 0.12 & 0.11 & 0.03 & 0.12 & 0.14 & 0.01 & 0.64 & & \\
\hline 12 & RG competition & 3.59 & 0.11 & 3.18 & 3.83 & 0.08 & 0.15 & 0.12 & 0.07 & 0.01 & -0.01 & 0.19 & 0.25 & 0.00 & 0.75 & 0.62 & \\
\hline 13 & $\begin{array}{l}\text { RG request received } \\
\text { Reference group withholding variables }\end{array}$ & 0.53 & 0.15 & 0.25 & 0.88 & 0.04 & 0.37 & 0.10 & 0.07 & -0.26 & 0.00 & 0.15 & 0.11 & -0.09 & 0.72 & 0.42 & 0.55 \\
\hline 14 & RG W/H level [same specialty] & 0.28 & 0.14 & 0 & 0.43 & 0.11 & -0.15 & 0.05 & 0.08 & 0.33 & -0.02 & -0.03 & 0.00 & 0.11 & 0.37 & 0.24 & -0.03 \\
\hline 15 & RG W/H level [same rank] & 0.25 & 0.20 & 0 & 2 & 0.14 & 0.01 & 0.06 & 0.03 & 0.07 & 0.03 & -0.04 & 0.03 & -0.02 & 0.06 & 0.11 & 0.04 \\
\hline 16 & RG W/H level [same experience] & 0.30 & 0.18 & 0 & 0.80 & 0.15 & -0.10 & 0.01 & 0.09 & 0.25 & -0.04 & 0.01 & -0.02 & 0.09 & 0.23 & 0.10 & -0.11 \\
\hline 17 & RG W/H level [same productivity] & 0.28 & 0.31 & 0 & 2 & 0.22 & 0.00 & 0.07 & 0.01 & 0.17 & -0.01 & 0.01 & 0.01 & 0.03 & 0.10 & 0.18 & -0.01 \\
\hline 18 & RG W/H level [same budget] & 0.29 & 0.36 & 0 & 6 & 0.22 & 0.03 & 0.12 & 0.08 & 0.19 & 0.04 & -0.03 & 0.03 & 0.08 & 0.11 & 0.22 & -0.01 \\
\hline 19 & RG W/H variance [same rank] & 0.80 & 0.46 & 0 & 1.52 & 0.14 & -0.05 & 0.10 & 0.08 & 0.35 & 0.10 & -0.02 & 0.02 & 0.01 & 0.38 & 0.40 & 0.15 \\
\hline 20 & RG W/H variance [same experience] & 1.03 & 0.73 & 0 & 3.42 & 0.04 & -0.09 & 0.00 & 0.07 & 0.04 & 0.00 & -0.01 & -0.05 & 0.05 & 0.15 & -0.05 & -0.35 \\
\hline 21 & RG W/H variance [same productivity] & 0.90 & 0.89 & 0 & 4.85 & 0.09 & -0.06 & -0.04 & +-0.03 & 0.03 & -0.01 & -0.01 & -0.04 & 0.03 & 0.11 & -0.02 & -0.20 \\
\hline 22 & RG W/H variance [same budget] & 0.94 & 0.86 & 0 & 5.66 & 0.07 & 0.00 & 0.07 & 0.10 & 0.05 & 0.06 & -0.01 & -0.03 & 0.06 & 0.10 & 0.06 & -0.25 \\
\hline 23 & RG W/H attitudes [higher rank] & 1.54 & 0.16 & 1 & 2 & 0.07 & -0.10 & -0.01 & 0.07 & 0.27 & -0.09 & -0.03 & 0.10 & 0.07 & 0.33 & 0.19 & 0.24 \\
\hline 24 & RG W/H attitudes [higher experience] & 1.55 & 0.20 & 1 & 3 & 0.09 & -0.05 & 0.04 & +0.00 & 0.17 & -0.13 & 0.04 & 0.03 & 0.11 & 0.20 & 0.11 & 0.11 \\
\hline 25 & RG W/H attitudes [higher productivity] & 1.55 & 0.18 & 1 & 3 & 0.08 & -0.06 & -0.01 & 0.00 & 0.21 & -0.07 & -0.05 & 0.02 & 0.07 & 0.24 & 0.15 & 0.09 \\
\hline 26 & RG W/H attitudes [higher budget] & 1.57 & 0.18 & 1 & 3 & 0.11 & -0.04 & 0.04 & 0.03 & 0.18 & -0.01 & -0.02 & -0.01 & 0.08 & 0.07 & 0.13 & -0.05 \\
\hline & Variable & 13 & 14 & 15 & 16 & 17 & 18 & 19 & 20 & 21 & 22 & 23 & 24 & 25 & & & \\
\hline & Reference group withholding variables & & & & & & & & & & & & & & & & \\
\hline 14 & RG W/H level [same specialty] & -0.53 & & & & & & & & & & & & & & & \\
\hline 15 & RG W/H level [same rank] & -0.06 & 0.17 & & & & & & & & & & & & & & \\
\hline 16 & RG W/H level [same experience] & -0.41 & 0.85 & 0.16 & & & & & & & & & & & & & \\
\hline 17 & RG W/H level [same productivity] & -0.17 & 0.45 & 0.12 & 0.38 & & & & & & & & & & & & \\
\hline 18 & RG W/H level [same budget] & -0.11 & 0.40 & 0.08 & 0.36 & 0.24 & & & & & & & & & & & \\
\hline 19 & RG W/H variance [same rank] & -0.27 & 0.69 & 0.91 & 0.58 & 0.36 & 0.32 & & & & & & & & & & \\
\hline 20 & RG W/H variance [same experience] & -0.33 & 0.72 & 0.12 & 0.83 & 0.31 & 0.32 & 0.34 & & & & & & & & & \\
\hline 21 & RG W/H variance [same productivity] & -0.24 & 0.49 & 0.13 & 0.43 & 0.77 & 0.17 & 0.28 & 0.53 & & & & & & & & \\
\hline 22 & RG W/H variance [same budget] & -0.18 & 0.53 & 0.12 & 0.53 & 0.23 & 0.71 & 0.31 & 0.68 & 0.35 & & & & & & & \\
\hline 23 & RG W/H attitudes [higher rank] & -0.37 & 0.61 & 0.08 & 0.54 & 0.23 & 0.15 & 0.30 & 0.29 & 0.14 & 0.16 & & & & & & \\
\hline 24 & RG W/H attitudes [higher experience] & -0.22 & 0.31 & 0.02 & 0.40 & 0.11 & 0.07 & 0.12 & 0.25 & 0.06 & 0.05 & 0.59 & & & & & \\
\hline 25 & RG W/H attitudes [higher productivity] & -0.26 & 0.49 & 0.11 & 0.40 & 0.36 & 0.18 & 0.39 & 0.25 & 0.37 & 0.16 & 0.47 & 0.25 & & & & \\
\hline 26 & RG W/H attitudes [higher budget] & -0.24 & 0.46 & 0.10 & 0.40 & 0.17 & 0.31 & 0.33 & 0.26 & 0.13 & 0.23 & 0.46 & 0.21 & 0.37 & & & \\
\hline
\end{tabular}

$\mathrm{P}<.05$ where $\mathrm{r}>.06$. Correlations are reported for the sample of 904 geneticists on which most of the analyses are based.

Descriptive statistics for reference group control variables shown here are calculated using averages of all reference group types. 
Table 2. Logistic analysis of the relationship between levels of information withholding in reference groups and withholding by life scientists ${ }^{1}$ (H1 and $\mathrm{H} 2$ )

\begin{tabular}{|c|c|c|c|c|c|c|}
\hline & M1 & M2 & M3 & M4 & M5 & M6 \\
\hline \multicolumn{7}{|l|}{ Individual control variables } \\
\hline Requests received & $\begin{array}{l}0.57 * \\
0.23)\end{array}$ & $\begin{array}{c}0.37 \\
(029)\end{array}$ & $\begin{array}{c}0.36 \\
(030)\end{array}$ & $\begin{array}{c}0.33 \\
(029)\end{array}$ & $\begin{array}{c}0.45 \\
(0.30)\end{array}$ & $\begin{array}{c}0.39 \\
(030)\end{array}$ \\
\hline Commercial activities & $0.44 *$ & $0.68^{*}$ & $0.58 *$ & $0.78 * *$ & $0.66^{*}$ & $0.62 *$ \\
\hline & $(0.22)$ & $(0.27)$ & $(0.28)$ & $(0.27)$ & $(0.28)$ & $(0.28)$ \\
\hline Industry support & 0.20 & 0.19 & 0.18 & 0.14 & 0.25 & 0.29 \\
\hline & $(0.25)$ & $(0.30)$ & $(0.30)$ & $(0.30)$ & $(0.30)$ & $(0.31)$ \\
\hline Human subjects & $0.58^{*}$ & 0.25 & 0.09 & 0.21 & 0.26 & 0.34 \\
\hline & $(0.24)$ & $(0.33)$ & $(0.34)$ & $(0.33)$ & $(0.33)$ & $(0.32)$ \\
\hline Male & $0.85 * *$ & $1.02 * *$ & $0.88^{*}$ & $1.02 * *$ & $1.07 * *$ & $0.97 *$ \\
\hline & $(0.30)$ & $(0.38)$ & $(0.39)$ & $(0.38)$ & $(0.39)$ & $(0.40)$ \\
\hline Own requests denied & $0.38+$ & 0.31 & 0.41 & 0.28 & 0.27 & 0.32 \\
\hline & $(0.22)$ & $(0.26)$ & $(0.27)$ & $(0.26)$ & $(0.26)$ & $(0.26)$ \\
\hline Perceived competition & $\begin{array}{c}0.33 \\
(0.23)\end{array}$ & $\begin{array}{l}0.55+ \\
(0.29)\end{array}$ & $\begin{array}{l}0.56+ \\
(0.31)\end{array}$ & $\begin{array}{l}0.56+ \\
(0.29)\end{array}$ & $\begin{array}{l}0.59+ \\
(0.31)\end{array}$ & $\begin{array}{l}0.55+ \\
(0.30)\end{array}$ \\
\hline Mentor withholding & $\begin{array}{l}0.30+ \\
(0.17)\end{array}$ & $\begin{array}{c}0.06 \\
(0.22)\end{array}$ & $\begin{array}{c}0.07 \\
(0.22)\end{array}$ & $\begin{array}{c}0.06 \\
(0.22)\end{array}$ & $\begin{array}{c}0.11 \\
(0.22)\end{array}$ & $\begin{array}{c}0.06 \\
(0.22)\end{array}$ \\
\hline Reference group control variables & & & & & & \\
\hline RG size & & $\begin{array}{l}-0.00 \\
(0.00)\end{array}$ & $\begin{array}{l}-0.00 \\
(0.01)\end{array}$ & $\begin{array}{l}-0.00 \\
(0.00)\end{array}$ & $\begin{array}{l}-0.00 \\
(0.01)\end{array}$ & $\begin{array}{c}0.00 \\
(0.00)\end{array}$ \\
\hline RG commercialization & & $\begin{array}{c}0.85 \\
(3.26)\end{array}$ & $\begin{array}{l}-0.35 \\
(1.44)\end{array}$ & $\begin{array}{c}0.13 \\
(1.66)\end{array}$ & $\begin{array}{l}-0.92 \\
(0.97)\end{array}$ & $\begin{array}{l}-0.19 \\
(1.05)\end{array}$ \\
\hline RG competition & & $\begin{array}{c}1.49 \\
(1.99)\end{array}$ & $\begin{array}{c}0.52 \\
(1.21)\end{array}$ & $\begin{array}{l}1.37 \\
(1.16)\end{array}$ & $\begin{array}{c}0.20 \\
(1.01)\end{array}$ & $\begin{array}{l}-0.72 \\
(1.15)\end{array}$ \\
\hline $\mathrm{RG}$ requests received & & $\begin{array}{c}0.68 \\
(1.90)\end{array}$ & $\begin{array}{l}0.01 \\
(0.97)\end{array}$ & $\begin{array}{c}0.63 \\
(1.42)\end{array}$ & $\begin{array}{l}-1.03 \\
(0.93)\end{array}$ & $\begin{array}{l}-0.29 \\
(1.02)\end{array}$ \\
\hline Reference group withholding variables & & & & & & \\
\hline RG W/H level [same field] & $\begin{array}{c}3.81 \\
(2.69)\end{array}$ & & & & & \\
\hline RG W/H level [same specialty] & & $\begin{array}{l}3.32 * \\
(1.49)\end{array}$ & & & & \\
\hline RG W/H level [same rank] & & & $\begin{array}{c}3.38^{* * *} \\
(0.82)\end{array}$ & & & \\
\hline RG W/H level [same experience] & & & & $\begin{array}{c}3.26 * * * \\
(0.90)\end{array}$ & & \\
\hline RG W/H level [same productivity] & & & & & $\begin{array}{c}1.78 * * * \\
(0.42)\end{array}$ & \\
\hline RG W/H level [same budget] & & & & & & $\begin{array}{c}1.36^{* * *} \\
(0.47)\end{array}$ \\
\hline Constant & $\begin{array}{c}-6.76 * * * \\
(1.27)\end{array}$ & $\begin{array}{c}-12.45+ \\
(7.04)\end{array}$ & $\begin{array}{l}-8.12+ \\
(4.29)\end{array}$ & $\begin{array}{c}-12.07 * * \\
(4.42)\end{array}$ & $\begin{array}{l}-6.27+ \\
(3.41)\end{array}$ & $\begin{array}{l}-3.46 \\
(3.72)\end{array}$ \\
\hline Degrees of freedom & 9 & 13 & 13 & 13 & 13 & 13 \\
\hline Log likelihood & -309.71 & -213.34 & -204.42 & -208.05 & -204.88 & -206.23 \\
\hline Model fit improvement ${ }^{2}$ & 2.11 & $5.27^{*}$ & $21.79 * * *$ & $14.46 * * *$ & $19.63 * * *$ & $10.70^{* * *}$ \\
\hline
\end{tabular}

${ }^{1} \mathrm{M} 1$ includes geneticists and nongeneticists, $\mathrm{n}=1,251 ; \mathrm{M} 2-\mathrm{M} 6$ includes geneticists only; $\mathrm{n}=904$.

${ }^{2}$ Relative to the same model excluding reference group variables. All statistics are $\chi^{2}$, calculated using likelihood-ratio tests.

$+\mathrm{p}<.1, * \mathrm{p}<.05, * * \mathrm{p}<.01, * * * \mathrm{p}<.001 ;$ standard errors in parentheses. 
Table 3. Logistic analysis of the relationship between variance in information withholding in reference groups and withholding by life scientists ${ }^{1}$ (H3)

\begin{tabular}{|c|c|c|c|c|c|c|c|c|}
\hline & M1 & M2 & M3 & M4 & M5 & M6 & M7 & M8 \\
\hline \multicolumn{9}{|l|}{ Individual control variables } \\
\hline Requests received & $\begin{array}{c}0.36 \\
(0.30)\end{array}$ & $\begin{array}{c}0.28 \\
(0.30)\end{array}$ & $\begin{array}{c}0.43 \\
(0.30)\end{array}$ & $\begin{array}{c}0.39 \\
(0.30)\end{array}$ & $\begin{array}{c}0.37 \\
(0.30)\end{array}$ & $\begin{array}{c}0.27 \\
(0.30)\end{array}$ & $\begin{array}{c}0.39 \\
(0.30)\end{array}$ & $\begin{array}{c}0.39 \\
(0.31)\end{array}$ \\
\hline Commercial activities & $\begin{array}{c}0.58^{*} \\
(0.28)\end{array}$ & $\begin{array}{c}0.81 * * \\
(0.28)\end{array}$ & $\begin{array}{c}0.70^{*} \\
(0.28)\end{array}$ & $\begin{array}{c}0.59 * \\
(0.29)\end{array}$ & $\begin{array}{l}0.64^{*} \\
(0.28)\end{array}$ & $\begin{array}{c}0.80^{* *} \\
(0.28)\end{array}$ & $\begin{array}{c}0.70^{*} \\
(0.29)\end{array}$ & $\begin{array}{l}0.60^{*} \\
(0.29)\end{array}$ \\
\hline Industry support & $\begin{array}{c}0.22 \\
(0.30)\end{array}$ & $\begin{array}{c}0.21 \\
(0.30)\end{array}$ & $\begin{array}{c}0.29 \\
(0.30)\end{array}$ & $\begin{array}{c}0.37 \\
(0.31)\end{array}$ & $\begin{array}{c}0.25 \\
(0.30)\end{array}$ & $\begin{array}{c}0.19 \\
(0.30)\end{array}$ & $\begin{array}{c}0.33 \\
(0.31)\end{array}$ & $\begin{array}{c}0.36 \\
(0.31)\end{array}$ \\
\hline Human subjects & $\begin{array}{c}0.02 \\
(0.34)\end{array}$ & $\begin{array}{c}0.08 \\
(0.34)\end{array}$ & $\begin{array}{c}0.27 \\
(0.34)\end{array}$ & $\begin{array}{c}0.24 \\
(0.33)\end{array}$ & $\begin{array}{c}0.06 \\
(0.34)\end{array}$ & $\begin{array}{c}0.05 \\
(0.34)\end{array}$ & $\begin{array}{c}0.13 \\
(0.34)\end{array}$ & $\begin{array}{c}0.19 \\
(0.33)\end{array}$ \\
\hline Male & $\begin{array}{l}0.90^{*} \\
(0.39)\end{array}$ & $\begin{array}{l}1.07 * * \\
(0.39)\end{array}$ & $\begin{array}{l}1.05 * * \\
(0.39)\end{array}$ & $\begin{array}{l}0.96^{*} \\
(0.40)\end{array}$ & $\begin{array}{l}0.96^{*} \\
(0.39)\end{array}$ & $\begin{array}{l}1.05^{* *} \\
(0.38)\end{array}$ & $\begin{array}{l}0.98 * \\
(0.39)\end{array}$ & $\begin{array}{l}0.95^{*} \\
(0.40)\end{array}$ \\
\hline Own requests denied & $\begin{array}{c}0.43 \\
(0.27)\end{array}$ & $\begin{array}{c}0.28 \\
(0.27)\end{array}$ & $\begin{array}{c}0.28 \\
(0.27)\end{array}$ & $\begin{array}{c}0.32 \\
(0.27)\end{array}$ & $\begin{array}{l}0.47+ \\
(0.27)\end{array}$ & $\begin{array}{c}0.30 \\
(0.27)\end{array}$ & $\begin{array}{c}0.30 \\
(0.27)\end{array}$ & $\begin{array}{c}0.29 \\
(0.27)\end{array}$ \\
\hline Perceived competition & $\begin{array}{l}0.58+ \\
(0.31)\end{array}$ & $\begin{array}{l}0.58 * \\
(0.29)\end{array}$ & $\begin{array}{l}0.57+ \\
(0.30)\end{array}$ & $\begin{array}{l}0.52+ \\
(0.30)\end{array}$ & $\begin{array}{l}0.55+ \\
(0.31)\end{array}$ & $\begin{array}{l}0.55+ \\
(0.29)\end{array}$ & $\begin{array}{l}0.52+ \\
(0.31)\end{array}$ & $\begin{array}{l}0.52+ \\
(0.30)\end{array}$ \\
\hline Mentor withholding & $\begin{array}{c}0.07 \\
(0.22)\end{array}$ & $\begin{array}{c}0.06 \\
(0.22)\end{array}$ & $\begin{array}{c}0.11 \\
(0.22)\end{array}$ & $\begin{array}{c}0.02 \\
(0.23)\end{array}$ & $\begin{array}{c}0.08 \\
(0.22)\end{array}$ & $\begin{array}{c}0.06 \\
(0.23)\end{array}$ & $\begin{array}{c}0.01 \\
(0.23)\end{array}$ & $\begin{array}{c}0.00 \\
(0.23)\end{array}$ \\
\hline Reference group control variables & & & & & & & & \\
\hline RG size & $\begin{array}{c}0.00 \\
(0.01)\end{array}$ & $\begin{array}{c}0.00 \\
(0.00)\end{array}$ & $\begin{array}{l}-0.00 \\
(0.01)\end{array}$ & $\begin{array}{c}0.00 \\
(0.00)\end{array}$ & $\begin{array}{c}0.00 \\
(0.01)\end{array}$ & $\begin{array}{l}-0.00 \\
(0.00)\end{array}$ & $\begin{array}{l}-0.00 \\
(0.01)\end{array}$ & $\begin{array}{c}0.00 \\
(0.00)\end{array}$ \\
\hline RG commercialization & $\begin{array}{l}-0.72 \\
(1.43)\end{array}$ & $\begin{array}{l}-0.39 \\
(1.88)\end{array}$ & $\begin{array}{l}-1.40 \\
(1.07)\end{array}$ & $\begin{array}{l}-0.02 \\
(1.19)\end{array}$ & $\begin{array}{l}-0.76 \\
(1.32)\end{array}$ & $\begin{array}{l}-0.43 \\
(1.92)\end{array}$ & $\begin{array}{l}-1.76 \\
(1.16)\end{array}$ & $\begin{array}{l}-0.21 \\
(1.21)\end{array}$ \\
\hline RG competition & $\begin{array}{l}-0.29 \\
(1.30)\end{array}$ & $\begin{array}{l}-1.29 \\
(1.34)\end{array}$ & $\begin{array}{l}-0.32 \\
(1.09)\end{array}$ & $\begin{array}{l}-1.92 \\
(1.37)\end{array}$ & $\begin{array}{l}-1.48 \\
(1.41)\end{array}$ & $\begin{array}{l}-1.38 \\
(1.32)\end{array}$ & $\begin{array}{l}-1.12 \\
(1.21)\end{array}$ & $\begin{array}{l}-2.52+ \\
(1.43)\end{array}$ \\
\hline $\mathrm{RG}$ requests received & $\begin{array}{l}-0.12 \\
(0.96)\end{array}$ & $\begin{array}{c}0.42 \\
(1.55)\end{array}$ & $\begin{array}{l}-1.06 \\
(0.98)\end{array}$ & $\begin{array}{l}-0.15 \\
(1.02)\end{array}$ & $\begin{array}{l}-0.04 \\
(0.97)\end{array}$ & $\begin{array}{c}0.38 \\
(1.68)\end{array}$ & $\begin{array}{l}-0.94 \\
(1.00)\end{array}$ & $\begin{array}{c}0.05 \\
(1.04)\end{array}$ \\
\hline Reference group withholding variables & & & & & & & & \\
\hline RG W/H level [same rank] & $\begin{array}{l}6.64 * * \\
(2.21)\end{array}$ & & & & $\begin{array}{c}11.72 * * * \\
(2.96)\end{array}$ & & & \\
\hline RG W/H level [same experience] & & $\begin{array}{l}6.23 * * \\
(1.37)\end{array}$ & & & & $\begin{array}{c}5.36 * * * \\
(1.50)\end{array}$ & & \\
\hline RG W/H level [same productivity] & & & $\begin{array}{c}2.16^{* *} \\
(0.77)\end{array}$ & & & & $\begin{array}{c}3.84 * * * \\
(1.03)\end{array}$ & \\
\hline RG W/H level [same budget] & & & & $\begin{array}{c}2.71 * * \\
(0.91)\end{array}$ & & & & $\begin{array}{c}3.95^{* *} \\
(1.15)\end{array}$ \\
\hline $\mathrm{RG} \mathrm{W} / \mathrm{H}$ variance [same rank] & $\begin{array}{l}-1.59 \\
(0.98)\end{array}$ & & & & $\begin{array}{l}-3.20 * * \\
(1.15)\end{array}$ & & & \\
\hline $\mathrm{RG} \mathrm{W} / \mathrm{H}$ variance [same experience] & & $\begin{array}{c}-1.20 * * \\
(0.42)\end{array}$ & & & & $\begin{array}{l}-0.75 \\
(0.50)\end{array}$ & & \\
\hline RG W/H variance [same productivity] & & & $\begin{array}{l}-0.21 \\
(0.25)\end{array}$ & & & & $\begin{array}{l}-0.01 \\
(0.26)\end{array}$ & \\
\hline RG W/H variance [same budget] & & & & $\begin{array}{l}-0.59 * \\
(0.29)\end{array}$ & & & & $\begin{array}{l}-0.72 * \\
(0.30)\end{array}$ \\
\hline RG W/H level*variance [same rank] & & & & & $\begin{array}{l}-5.28^{*} \\
(2.17)\end{array}$ & & & \\
\hline RG W/H level*variance [same experience] & & & & & & $\begin{array}{c}-2.44+ \\
(1.47)\end{array}$ & & \\
\hline RG W/H level*variance [same productivity] & & & & & & & $\begin{array}{c}-1.73 * * \\
(0.63)\end{array}$ & \\
\hline RG W/H level*variance [same budget] & & & & & & & & $\begin{array}{c}-0.51^{*} \\
(0.26)\end{array}$ \\
\hline Constant & $\begin{array}{c}-4.97 \\
(4.68)\end{array}$ & $\begin{array}{l}-2.18 \\
(5.09)\end{array}$ & $\begin{array}{l}-4.15 \\
(3.69)\end{array}$ & $\begin{array}{c}0.96 \\
(4.46)\end{array}$ & $\begin{array}{c}0.16 \\
(4.98)\end{array}$ & $\begin{array}{c}-0.66 \\
(4.86)\end{array}$ & $\begin{array}{c}-0.04 \\
(4.20)\end{array}$ & $\begin{array}{c}3.38 \\
(4.68)\end{array}$ \\
\hline Degrees of freedom & 14 & 14 & 14 & 14 & 15 & 15 & 15 & 15 \\
\hline Log likelihood & -202.98 & -203.28 & -201.88 & -202.46 & -199.86 & -201.75 & -197.71 & -200.92 \\
\hline Model fit improvement ${ }^{2}$ & $24.67 * * *$ & $24.00 * * *$ & $25.63 * * *$ & $18.24 * * *$ & $30.89 * * *$ & $27.06 * * *$ & $33.96 * * *$ & $21.32 * * *$ \\
\hline
\end{tabular}


Table 4. Logistic analysis of the relationship between attitudes to information withholding in reference groups of status-superiors and withholding by life scientists $^{1}$ (H4)

\begin{tabular}{|c|c|c|c|c|}
\hline & M1 & M2 & M3 & M4 \\
\hline \multicolumn{5}{|l|}{ Individual control variables } \\
\hline Requests received & $\begin{array}{l}-0.45 \\
(0.42)\end{array}$ & $\begin{array}{c}0.40 \\
(0.29)\end{array}$ & $\begin{array}{l}0.50+ \\
(0.30)\end{array}$ & $\begin{array}{c}0.49 \\
(0.31)\end{array}$ \\
\hline Commercial activities & $\begin{array}{l}1.28 * * \\
(0.42)\end{array}$ & $\begin{array}{c}0.75^{* *} \\
(0.27)\end{array}$ & $\begin{array}{c}0.88^{* *} * \\
(0.27)\end{array}$ & $\begin{array}{c}0.79^{* *} \\
(0.28)\end{array}$ \\
\hline Industry support & $\begin{array}{c}0.29 \\
(0.43)\end{array}$ & $\begin{array}{c}0.29 \\
(0.31)\end{array}$ & $\begin{array}{c}0.25 \\
(0.31)\end{array}$ & $\begin{array}{c}0.39 \\
(0.32)\end{array}$ \\
\hline Human subjects & $\begin{array}{l}-0.34 \\
(0.58)\end{array}$ & $\begin{array}{c}0.31 \\
(0.33)\end{array}$ & $\begin{array}{c}0.46 \\
(0.33)\end{array}$ & $\begin{array}{c}0.33 \\
(0.33)\end{array}$ \\
\hline Male & $\begin{array}{l}1.39 * \\
(0.58)\end{array}$ & $\begin{array}{l}1.10 * * \\
(0.39)\end{array}$ & $\begin{array}{l}1.02 * * \\
(0.39)\end{array}$ & $\begin{array}{l}1.03^{*} \\
(0.40)\end{array}$ \\
\hline Own requests denied & $\begin{array}{l}0.90^{*} \\
(0.41)\end{array}$ & $\begin{array}{c}0.35 \\
(0.27)\end{array}$ & $\begin{array}{c}0.27 \\
(0.27)\end{array}$ & $\begin{array}{c}0.43 \\
(0.27)\end{array}$ \\
\hline Perceived competition & $\begin{array}{c}0.94+ \\
(0.54)\end{array}$ & $\begin{array}{l}0.51+ \\
(0.29)\end{array}$ & $\begin{array}{l}0.54+ \\
(0.30)\end{array}$ & $\begin{array}{l}0.55+ \\
(0.30)\end{array}$ \\
\hline Mentor withholding & $\begin{array}{l}-0.37 \\
(0.36)\end{array}$ & $\begin{array}{l}-0.00 \\
(0.23)\end{array}$ & $\begin{array}{l}-0.03 \\
(0.23)\end{array}$ & $\begin{array}{l}-0.04 \\
(0.24)\end{array}$ \\
\hline Attitude to withholding & $\begin{array}{l}0.58+ \\
(0.31)\end{array}$ & $\begin{array}{c}0.55^{* *} \\
(0.19)\end{array}$ & $\begin{array}{c}0.60^{* *} \\
(0.19)\end{array}$ & $\begin{array}{c}0.65^{* *} \\
(0.19)\end{array}$ \\
\hline Reference group control variables & & & & \\
\hline RG size & $\begin{array}{c}0.00 \\
(0.01)\end{array}$ & $\begin{array}{l}-0.00 \\
(0.01)\end{array}$ & $\begin{array}{c}-0.01 \\
(0.00)\end{array}$ & $\begin{array}{l}-0.00 \\
(0.00)\end{array}$ \\
\hline RG commercialization & $\begin{array}{l}-3.26 \\
(2.84)\end{array}$ & $\begin{array}{c}-0.86 \\
(1.17)\end{array}$ & $\begin{array}{c}-1.64+ \\
(0.88)\end{array}$ & $\begin{array}{c}-0.88 \\
(1.02)\end{array}$ \\
\hline RG competition & $\begin{array}{c}-0.99 \\
(1.73)\end{array}$ & $\begin{array}{c}0.26 \\
(0.96)\end{array}$ & $\begin{array}{c}-0.54 \\
(0.77)\end{array}$ & $\begin{array}{c}-0.34 \\
(0.77)\end{array}$ \\
\hline $\mathrm{RG}$ requests received & $\begin{array}{c}1.26 \\
(1.80)\end{array}$ & $\begin{array}{l}-0.51 \\
(0.79)\end{array}$ & $\begin{array}{c}-0.57 \\
(0.95)\end{array}$ & $\begin{array}{c}-0.71 \\
(0.98)\end{array}$ \\
\hline Reference group withholding & & & & \\
\hline RG W/H attitudes [higher rank] & $\begin{array}{l}3.43+ \\
(1.75)\end{array}$ & & & \\
\hline RG W/H attitudes [higher experience] & & $\begin{array}{c}2.11 * * \\
(0.75)\end{array}$ & & \\
\hline RG W/H attitudes [higher productivity] & & & $\begin{array}{l}2.02 * \\
(0.82)\end{array}$ & \\
\hline RG W/H attitudes [higher budget] & & & & $\begin{array}{l}1.82^{*} \\
(0.77)\end{array}$ \\
\hline Constant & $\begin{array}{c}-9.53 \\
(6.54) \\
\end{array}$ & $\begin{array}{c}-10.13^{*} \\
(4.16) \\
\end{array}$ & $\begin{array}{l}-6.68^{*} \\
(3.21) \\
\end{array}$ & $\begin{array}{c}-7.76^{* * *} \\
(2.97) \\
\end{array}$ \\
\hline Degrees of freedom & 14 & 14 & 14 & 14 \\
\hline Log likelihood & -95.08 & -201.32 & -199.16 & -194.07 \\
\hline Model fit improvement $^{2}$ & $4.58 *$ & $8.03 * *$ & $6.22 *$ & $6.01 *$ \\
\hline
\end{tabular}

${ }^{1}$ All models include geneticists only, $\mathrm{n}=904$.

${ }^{2}$ Relative to the same model excluding reference group variables. All statistics are $\chi^{2}$, calculated using likelihood-ratio tests.

$+\mathrm{p}<.1, * \mathrm{p}<.05, * * \mathrm{p}<.01, * * * \mathrm{p}<.001 ;$ standard errors in parentheses. 
${ }^{1}$ In this paper, science refers to the academic natural sciences, including the physical and life sciences.

${ }^{2}$ According to Merton, sociological ambivalence differs from psychological ambivalence arising from contradictory emotions, conflicting ideas, or confusion over how to act to fulfill one's wishes (cf. Jansen and Von Glinow 1985, Smelser 1998, Pratt 2000). He argued that while sociological ambivalence is a major source of psychological ambivalence, "people are exposed to [sociological ambivalence] not because of their idiosyncratic history or distinctive personality, but because the ambivalence is inherent in the social positions they occupy" (Merton and Barber 1963: 96). Sociological ambivalence also differs from role conflict, which according to role theory arises from the contradictory demands of one or more role-senders (Katz and Kahn 1966), because it arises from contradictory role expectations that are not imposed by particular role-senders, but instead result from conflicting professional norms. ${ }^{3}$ In additional analyses, we examined alternative dependent variables that captured whether a scientist denied requests for information related to unpublished rather than published research, the number of denials reported, and substantial delays in responding to requests for information related to both unpublished and published research. The results were similar to those reported here.

${ }^{4}$ Sensitivity tests indicated that the criteria used to construct these moving windows were robust to minor modifications and that using categorical measures rather than moving windows also gave similar results. Additionally, the results were similar if different specifications were used to define status-superiors, such as those at the next rank or experience level rather than those of any higher rank or experience.

${ }^{5}$ Consistent with prior studies of contextual effects on the behavior of scientists (e.g., Louis et al. 1989), as well as with the extensive literature on endogenous social effects (including sociological research on peer influence in schools and economic research on market supply and demand), we retained the focal scientist's observation in the higher-level group for these reference group withholding variables and also the reference group control variables. Because of the cross-sectional nature of the data, excluding that observation would introduce a systematic bias in the analyses. For example, if the excluded scientist had withheld, the group's level of withholding would appear lower than if the excluded scientist had not withheld, creating an artificial negative association between withholding in the group and withholding by the scientist. Although retaining the focal scientist's observation avoids inducing such bias, it can create a "reflection problem" (Manski 1993), as it may be difficult to determine whether the average behavior in a group causes or reflects the individual's behavior. In the present study, however, this concern is alleviated because including focal scientists in the averages for their reference groups is clearly less problematic when those groups are larger; at the extreme, if a reference group includes one million scientists, the exclusion of the focal scientist makes no difference. To ensure that the results of this study were not simply attributable to small groups where focal scientists' behaviors contributed substantially to the group averages, we ran our analyses using a limited data set that omitted the smallest groups (up to $40 \%$ of all the groups in each analysis). The results of the study still held, indicating that the effects were robust for groups to which the focal scientists' own behaviors contributed little.

${ }^{6}$ Alternatively, the extent of information withholding could be measured by the proportion of the reference group members who refused at least one request. This variable was highly correlated with the average-based variable $(\mathrm{r}=$ 0.85 or above) and gives the same results, so we report the results for the average-based variable only.

${ }^{7}$ An alternative measure is the coefficient of variation (the ratio of the standard deviation to the mean), but this was not appropriate here because the mean values in the reference group categories were often close to zero, making it too sensitive to changes in the standard deviation, and also because it confounds two characteristics of reference group behaviors, the standard deviation and the mean, creating interpretation problems (Sorensen 2002).

${ }^{8}$ We examined whether our results were sensitive to reference groups with very small members, such as zebra fish, but found they were not.

${ }^{9}$ We also examined the influence of specialty discovery rates directly by measuring the total number of academic journal articles in that specialty between 1997 and 2000, the period addressed in the survey, as listed in the Science Citation Index (SCI). Higher annual publication rates are assumed to reflect higher discovery rates. We found no significant effects of this reference group control variable on withholding behavior, nor any significant interactions with individual control variables such as the focal scientist's rank.

${ }^{10} \mathrm{We}$ also tested continuous measures and found no differences in the results.

${ }^{11}$ This likely constitutes a lower bound estimate of the actual incidence of withholding, given that survey respondents are often reluctant to report engaging in socially undesirable behavior (Fowler 1993). 